\title{
Insights into mechanisms governing forest carbon response to nitrogen deposition: a model-data comparison using observed responses to nitrogen addition
}

\author{
R. Q. Thomas ${ }^{1,2}$, G. B. Bonan ${ }^{2}$, and C. L. Goodale ${ }^{1}$ \\ ${ }^{1}$ Department of Ecology and Evolutionary Biology, Cornell University, Ithaca, NY, USA \\ ${ }^{2}$ National Center for Atmospheric Research, Boulder, CO, USA \\ Correspondence to: R. Q. Thomas (rqthomas@vt.edu)
}

Received: 11 January 2013 - Published in Biogeosciences Discuss.: 31 January 2013

Revised: 5 May 2013 - Accepted: 6 May 2013 - Published: 17 June 2013

\begin{abstract}
In many forest ecosystems, nitrogen (N) deposition enhances plant uptake of carbon dioxide, thus reducing climate warming from fossil fuel emissions. Therefore, accurately modeling how forest carbon (C) sequestration responds to $\mathrm{N}$ deposition is critical for understanding how future changes in $\mathrm{N}$ availability will influence climate. Here, we use observations of forest $\mathrm{C}$ response to $\mathrm{N}$ inputs along $\mathrm{N}$ deposition gradients and at five temperate forest sites with fertilization experiments to test and improve a global biogeochemical model (CLM-CN 4.0). We show that the CLM-CN plant $\mathrm{C}$ growth response to $\mathrm{N}$ deposition was smaller than observed and the modeled response to $\mathrm{N}$ fertilization was larger than observed. A set of modifications to the CLM$\mathrm{CN}$ improved the correspondence between model predictions and observational data (1) by increasing the aboveground $\mathrm{C}$ storage in response to historical $\mathrm{N}$ deposition (1850-2004) from 14 to $34 \mathrm{~kg} \mathrm{C}$ per additional $\mathrm{kg} \mathrm{N}$ added through deposition and (2) by decreasing the aboveground net primary productivity response to $\mathrm{N}$ fertilization experiments from 91 to $57 \mathrm{~g} \mathrm{C} \mathrm{m}^{-2} \mathrm{yr}^{-1}$. Modeled growth response to $\mathrm{N}$ deposition was most sensitive to altering the processes that control plant $\mathrm{N}$ uptake and the pathways of $\mathrm{N}$ loss. The response to $\mathrm{N}$ deposition also increased with a more closed $\mathrm{N}$ cycle (reduced $\mathrm{N}$ fixation and $\mathrm{N}$ gas loss) and decreased when prioritizing microbial over plant uptake of soil inorganic $\mathrm{N}$. The net effect of all the modifications to the CLM-CN resulted in greater retention of $\mathrm{N}$ deposition and a greater role of synergy between $\mathrm{N}$ deposition and rising atmospheric $\mathrm{CO}_{2}$ as a mechanism governing increases in temperate forest primary production over the 20th century. Overall, testing models with both the
\end{abstract}

response to gradual increases in $\mathrm{N}$ inputs over decades ( $\mathrm{N}$ deposition) and $\mathrm{N}$ pulse additions of $\mathrm{N}$ over multiple years ( $\mathrm{N}$ fertilization) allows for greater understanding of the mechanisms governing $\mathrm{C}-\mathrm{N}$ coupling.

\section{Introduction}

Reactive nitrogen $(\mathrm{N})$ from fossil fuel combustion and agricultural activities influences global climate by altering atmospheric chemistry, aerosols, and greenhouse gas concentrations (Butterbach-Bahl et al., 2011; Pinder et al., 2012). However, the direction of the climate impact of reactive $\mathrm{N}$ primarily depends on the balance of opposing processes: positive radiative forcing from emissions of $\mathrm{N}_{2} \mathrm{O}$, a greenhouse gas, and negative radiative forcing from altered atmospheric chemistry and carbon dioxide $\left(\mathrm{CO}_{2}\right)$ storage in $\mathrm{N}$-fertilized forests (Arneth et al., 2010; Pinder et al., 2012). Reactive $\mathrm{N}$ deposited on forest ecosystems can increase primary production if the forest is $\mathrm{N}$ limited (Nadelhoffer et al., 1999; Magnani et al., 2007; Thomas et al., 2010), which results in less $\mathrm{CO}_{2}$ in the atmosphere and consequently reduced climate warming. Recent estimates show that this $\mathrm{CO}_{2}$ uptake broadly offsets warming from $\mathrm{N}_{2} \mathrm{O}$ emissions, indicating that the $\mathrm{N}$-induced forest sink of $\mathrm{CO}_{2}$ has an important role in global climate (Zaehle et al., 2011; Butterbach-Bahl et al., 2011; Pinder et al., 2012).

Accurately predicting how carbon (C) storage in forest ecosystems will respond to the changing deposition of reactive $\mathrm{N}$ is critical for developing climate change targets 
for reducing emissions and air pollution. Global biogeochemical models coupled to climate and atmospheric chemistry models are powerful tools for exploring this carbonnitrogen-climate interface (Sokolov et al., 2008; Thornton et al., 2009; Yang et al., 2009; Zaehle and Friend, 2010), but it is paramount to build confidence in predictions of how $\mathrm{C}$ uptake and storage respond to changing $\mathrm{N}$ inputs.

Fortunately, a variety of observational and experimental data are available to test and improve the sensitivity of global biogeochemical models to changes in $\mathrm{N}$ deposition and the resulting $\mathrm{C}$ sequestration. Studies have generally shown that elevated $\mathrm{N}$ inputs often increase plant growth and soil $\mathrm{C}$ sequestration (Magnani et al., 2007; Hyvonen et al., 2008; de Vries et al., 2009; Janssens et al., 2010; Thomas et al., 2010), although some ecosystems can be harmed by chronic elevated $\mathrm{N}$ inputs that lead to soil acidification and $\mathrm{N}$ saturation (Aber et al., 1998; Hogberg et al., 2006; Wallace et al., 2007). The current range of estimates quantifying the additional $\mathrm{C}$ sequestered per unit of $\mathrm{N}$ added $(\mathrm{kg} \mathrm{C}$ per $\mathrm{kg} \mathrm{N}$, or $\mathrm{dC} / \mathrm{dN}$ ) is broad, in part due to the myriad of approaches used to quantify $\mathrm{dC} / \mathrm{dN}$. These approaches include $\mathrm{N}$ fertilization studies (Hyvonen et al., 2008; Liu and Greaver, 2009), where large inputs of $\mathrm{N}$ are added to forests over short timescales, and $\mathrm{N}$ deposition gradient studies (Magnani et al., 2007; de Vries et al., 2009; Thomas et al., 2010), where spatial variation in $\mathrm{N}$ deposition and forest growth are used to estimate the impact of gradual increases in $\mathrm{N}$ deposition on $\mathrm{C}$ storage over multiple decades. Furthermore, there can be variation among studies in the $\mathrm{C}$ pools being measured, as some studies calculate the $\mathrm{dC} / \mathrm{dN}$ of aboveground stem $\mathrm{C}$ (de Vries et al., 2009; Thomas et al., 2010), soil organic matter (Janssens et al., 2010), or net ecosystem production (NEP; Magnani et al., 2007; Sutton et al., 2008). Finally, the observations span regions with very different historical $\mathrm{N}$ deposition loads (i.e., the US compared to Western Europe). Successfully using the available data to test and improve global biogeochemical models requires directly accounting for the variation in magnitude and timescale of $\mathrm{N}$ additions in the observational and experimental data.

Many different approaches have been used to model key processes influencing $\mathrm{C}$ and $\mathrm{N}$ cycle interactions in terrestrial ecosystems (Zaehle and Dalmonech, 2011). For example, $\mathrm{N}$ fixation has been modeled as a function of net primary production (NPP) (Thornton et al., 2007), evapotranspiration (Felzer, 2012; Tian et al., 2011; Yang et al., 2009; Zaehle and Friend, 2010) or N demand (Gerber et al., 2010). Similarly, $\mathrm{N}$ uptake has been represented as a direct function of photosynthesis and $\mathrm{C}: \mathrm{N}$ stoichiometric constraints on building plant tissue (Thornton et al., 2002, 2007) or based on allocation of C to plant roots (Gerber et al., 2010; Raich et al., 1991; Zaehle and Friend, 2010). Soil and plant buffering of the $\mathrm{C}$ cycle to daily to annual changes in $\mathrm{N}$ availability also differs among models (Gerber et al., 2010; Zaehle and Friend, 2010). Despite these differences, global biogeochemical models predict reasonable levels of global NPP (Thorn- ton et al., 2007; Gerber et al., 2010; Zaehle et al., 2010a), suggesting that the representation or parameterization of one $\mathrm{C}-\mathrm{N}$ process may compensate for the representation or parameterization of another. Understanding how the different model structures or parameterizations influence the prediction of how ecosystems respond to $\mathrm{N}$ deposition requires isolating key processes that govern $\mathrm{C}$ and $\mathrm{N}$ interactions. Unfortunately, intermodel comparisons can be limited by broad differences in model structure that make it difficult to isolate particular processes that differ among models. One approach to this problem is to compare different representations of particular $\mathrm{C}$ and $\mathrm{N}$ cycle processes within the same general model, thereby obtaining a better understanding of which processes influence predictions of how terrestrial $\mathrm{C}$ storage and climate respond to changing $\mathrm{N}$ availability.

Here, we explored the influence of alternative approaches to modeling $\mathrm{C}$ and $\mathrm{N}$ interactions on the sensitivity of $\mathrm{C}$ storage to $\mathrm{N}$ inputs in temperate forest ecosystems. To isolate the alternative approaches, we implemented multiple alternative assumptions about $\mathrm{C}$ and $\mathrm{N}$ cycling within a single global biogeochemical land surface model (CLM-CN 4.0). We focused on five key assumptions about the $\mathrm{N}$ cycle in the CLM-CN 4.0: (1) the extent to which the N cycle is open, based on $\mathrm{N}$ fixation inputs and $\mathrm{N}$ losses relative to internal $\mathrm{N}$ cycling, (2) the buffering of the soil inorganic $\mathrm{N}$ pool and plant $\mathrm{N}$ pool, (3) the representation of plant $\mathrm{N}$ uptake, (4) the pathways of $\mathrm{N}$ loss, and (5) the canopy scaling of photosynthesis. These alternative assumptions are combined to create a modified version of the CLM-CN 4.0 that is compared to observed ecosystem response to experimental $\mathrm{N}$ fertilization and to elevated $\mathrm{N}$ inputs across $\mathrm{N}$ deposition gradients.

\section{Methods}

\subsection{Baseline model description}

We used the CLM-CN 4.0 as the baseline model (Lawrence et al., 2011, 2012). The CLM-CN 4.0 is the global land surface model in the Community Earth System Model (Gent et al., 2011) and includes both terrestrial biogeophysical and biogeochemical processes. Our model simulations include both the biogeophysical and biogeochemical components of the CLM-CN, but we focus our model evaluation and improvement on the biogeochemical component (hereafter, referred to as the "clm4cn" model). A description of the key processes that relate to new model modifications are described below, while a more thorough description of the biogeochemical component can be found elsewhere (Thornton et al., 2002, 2007, 2009; Thornton and Rosenbloom, 2005). In the $\mathrm{clm} 4 \mathrm{cn}$ model, the $\mathrm{C}$ and $\mathrm{N}$ cycles are coupled through litter and soil organic matter decomposition and through plant dynamics. The primary $\mathrm{C}$ and $\mathrm{N}$ coupling occurs on the 30 min timescale, as plants compete for $\mathrm{N}$ with microbial immobilization in soil organic matter, where $\mathrm{N}$ comes from a 
generic soil inorganic $\mathrm{N}$ pool (i.e., $\mathrm{NH}_{4}^{+}$and $\mathrm{NO}_{3}^{-}$are combined). Plant $\mathrm{N}$ demand is based on the $\mathrm{N}$ needed to match the demand set by non-N-limited photosynthesis and plant tissue $\mathrm{C}: \mathrm{N}$ stoichiometric constraints. If the combined $\mathrm{N}$ demand exceeds the available $\mathrm{N}$ in soil and retranslocated from senescent plant tissue, plant uptake and microbial immobilization are reduced in proportion to the available $\mathrm{N}$ and their relative demands. Sources of new $\mathrm{N}$ into the $\mathrm{clm} 4 \mathrm{cn}$ model include $\mathrm{N}$ fixation and $\mathrm{N}$ deposition. $\mathrm{N}$ losses include denitrification, leaching, fire, and harvest. $\mathrm{N}$ fixation is a saturating function of NPP derived from Cleveland et al. (1999). Fixation and deposition are both directly added to the soil inorganic $\mathrm{N}$ pool. The $\mathrm{clm} 4 \mathrm{cn}$ model includes both denitrification and leaching processes; however, the vast majority of $\mathrm{N}$ is lost as $\mathrm{N}$ gas in most ecosystems in the model (Table A2). Therefore, the two loss pathways for $\mathrm{N}$ gases in the clm4cn model are very important: (1) a constant $1 \%$ of net mineralization is lost as $\mathrm{N}$ gas and (2) the soil inorganic $\mathrm{N}$ that exceeds plant uptake and immobilization is denitrified at a rate of $50 \%$ per day.

\subsection{Modified model description}

The overall model modifications (referred to as "clm4mod") build on recent improvements to the calculations of canopy photosynthesis in the clm4cn (Bonan et al., 2011, 2012) by modifying the representations of plant $\mathrm{N}$ uptake, internal $\mathrm{N}$ cycling, $\mathrm{N}$ loss, and biological $\mathrm{N}$ fixation in mature temperate and boreal forests. The modifications within the $\mathrm{clm} 4 \mathrm{cn}$ reflect differences between the $\operatorname{clm} 4 \mathrm{cn}$ and other global biogeochemical models, specially models that have alternative approaches to modeling $\mathrm{N}$ uptake $(\mathrm{O}-\mathrm{CN}$ : $\mathrm{Za}-$ ehle and Friend, 2010; LM3V: Gerber et al., 2010), buffering of plant and soil $\mathrm{N}$ availability (O-CN: Zaehle and Friend, 2010; LM3V: Gerber et al., 2010) and less N fixation in temperate and boreal forests than the $\operatorname{clm} 4 \mathrm{cn}$ (LM3V; Gerber et al., 2010). An overview of the modifications is found below, while a full description is found in Appendix A.

\subsubsection{Internal $\mathbf{N}$ cycling}

Plant $\mathrm{N}$ uptake in the clm4mod model is based on MichaelisMenten kinetics, where the rate of $\mathrm{N}$ uptake depends on a maximum uptake rate per gram of fine root $\mathrm{C}$, as well as the concentration of soil inorganic $\mathrm{N}$ in separate $\mathrm{NH}_{4}^{+}$and $\mathrm{NO}_{3}^{-}$pools (see Appendix A for detailed information). Plant uptake increases with soil temperature and as the internal plant pool of $\mathrm{N}$ decreases relative to a maximum internal pool. The formulation of $\mathrm{N}$ uptake is similar to that used in other global biogeochemical models (Gerber et al., 2010; Zaehle and Friend, 2010) and differs from the clm4cn by allowing the $\mathrm{N}$ uptake to be decoupled from photosynthesis at short timescales (i.e., seconds to days); longer-term $\mathrm{N}$ uptake (i.e., at days to years) remains ultimately coupled to photosynthesis. The maximum internal plant $\mathrm{N}$ pool is equal to one year of live plant tissue $\mathrm{N}$ turnover (Gerber et al., 2010). In the clm4mod model, the maximum uptake rate is assumed to be equal for $\mathrm{NH}_{4}^{+}$and $\mathrm{NO}_{3}^{-}$, as implemented in other models (Gerber et al., 2010; Zaehle and Friend, 2010). N uptake occurs any time during the growing season (i.e., when leaves are present on the plant), rather than only during the day within the growing season, as implemented in the clm $4 \mathrm{cn}$ model. Plant uptake is assumed to be less competitive for $\mathrm{N}$ than soil immobilization of $\mathrm{N}$, in that plant uptake occurs after soil microbial immobilization demands are met; in the $\operatorname{clm} 4 \mathrm{cn}$, neither plant uptake nor soil immobilization of $\mathrm{N}$ had first access to soil inorganic $\mathrm{N}$, rather they compete based on their demand for $\mathrm{N}$. The clm4mod includes a plant labile $\mathrm{N}$ (short/medium-term storage) pool that is used to buffer the demand for $\mathrm{N}$ from photosynthesis from the uptake of $\mathrm{N}$ by roots. The buffering occurs by allowing only $2 \%$ of the plant labile $\mathrm{N}$ pool to be available for combining with new photosynthate to build plant tissue. The $2 \%$ buffering capacity leads to approximately a two-day turnover time of labile plant $\mathrm{N}$. The clm $4 \mathrm{cn}$ does not include buffering of labile plant $\mathrm{N}$.

\subsubsection{N losses}

The clm4mod model introduces a nitrification algorithm, an alternative denitrification algorithm, and a simple algorithm describing the production and hydrologic loss of dissolved organic matter (DOM), including dissolved organic $\mathrm{N}$ (DON). Nitrification is a function of soil $\mathrm{NH}_{4}^{+}$, soil temperature, soil water, and net mineralization based on Parton et al. (2001) with $2 \%$ of nitrification lost as $\mathrm{N}_{2} \mathrm{O}$ (Parton et al., 2001). Denitrification is an function of soil $\mathrm{NO}_{3}^{-}$, soil water, and soil heterotrophic activity based on Bradbury et al. (1993; Appendix A5; Yang et al., 2009). To buffer the availability of soil inorganic $\mathrm{N}$ and approximate shortterm cation exchange processes, $10 \%$ of total soil $\mathrm{NH}_{4}^{+}$is available for immobilization, plant uptake, nitrification, and leaching (Gerber et al., 2010), and, since $\mathrm{NO}_{3}^{-}$is highly mobile in soils, $100 \%$ of $\mathrm{NO}_{3}^{-}$is assumed to be available for soil, plant, and loss processes. Dissolved organic matter is produced at a constant proportion $(1.5 \%)$ of the organic matter transfer between the slow litter pool (lignin-based) and its receiving soil organic matter pool (based on Gerber et al., 2010). Both dissolved organic $\mathrm{C}$ and $\mathrm{N}$ are lost in proportion to hydrologic export, similar to leaching loss of soil inorganic $\mathrm{N}$ in the clm4cn model. The clm $4 \mathrm{cn}$ does not include separate consideration of $\mathrm{NH}_{4}^{+}$and $\mathrm{NO}_{3}^{-}$and cycling, nor does it include DOC and DON losses.

\subsubsection{N inputs}

In clm4mod $\mathrm{N}$ fixation is a function of actual evapotranspiration, based on the central relationship in the Cleveland et al. (1999) review of $\mathrm{N}$ fixation measurements, rather than a function of NPP, as implemented in $\mathrm{clm} 4 \mathrm{cn}$. In addition, 
Table 1. Descriptions of sites used in model simulations.

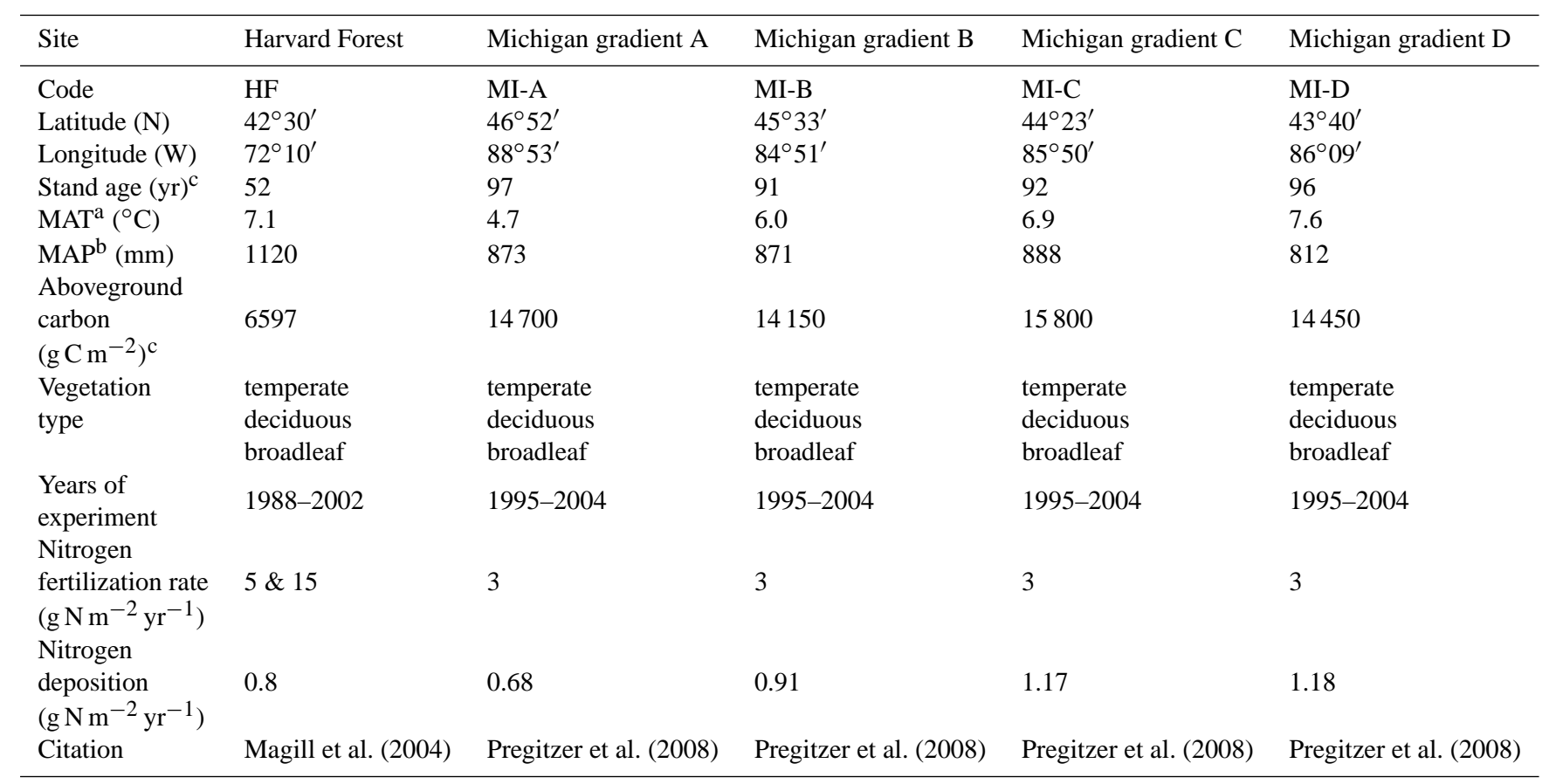

${ }^{a}$ Mean annual temperature.

b Mean annual precipitation.

c Age and carbon stocks in the year 1994.

symbiotic and non-symbiotic sources of $\mathrm{N}$ fixation are separated. Symbiotic fixation is added to the labile $\mathrm{N}$ pool and non-symbiotic fixation is added to the soil $\mathrm{NH}_{4}^{+}$pool. Symbiotic $\mathrm{N}$ fixation is assumed to be zero in mid- to latesuccessional temperate and boreal forests (i.e., when leaf area index $(\mathrm{LAI}) \geq 1$, and non-symbiotic $\mathrm{N}$ fixation increases with actual evapotranspiration (Appendix A6). Both sources of fixation are assumed to occur in grasslands and tropical forests. This $\mathrm{N}$ fixation routine reduces the overall $\mathrm{N}$ inputs to mid- to late-successional extratropical forests (see Table A2 for the magnitude of change in $\mathrm{N}$ fixation). A pathway for $\mathrm{N}$ fertilization was also added to facilitate the simulation of $\mathrm{N}$ fertilization experiments.

$\mathrm{N}$ deposition in the clm4mod was equal to total $\mathrm{N}$ deposition in the $\operatorname{clm} 4 \mathrm{cn}$, except $\mathrm{N}$ deposition in the $\mathrm{clm} 4 \bmod$ was divided into $\mathrm{NH}_{4}^{+}$and $\mathrm{NO}_{3}^{-}$based on the $\mathrm{N}$ deposition input fields described in Lamarque et al. (2005).

\subsubsection{Canopy photosynthesis}

Finally, the clm4mod model includes changes to the canopy scaling of photosynthesis, maximum photosynthetic rates, radiative transfer, leaf photosynthesis, and stomatal conductance as described in Bonan et al. $(2011,2012)$. Bonan et al. (2012) introduced a multi-layer canopy scaling approach that solved photosynthesis throughout the canopy rather than using a whole canopy approximation. The model updates in Bonan et al. $(2011,2012)$ decreased gross primary produc- tion and effectively reduced the photosynthetic potential of shaded leaves, but the impact of the changes on $\mathrm{C}-\mathrm{N}$ interactions has not been investigated. The clm 4 mod model also includes specific values of maximum photosynthetic rate for each plant functional type from a synthesis of a plant trait database (Kattge et al., 2009), although these values differed only slightly from the values in the clm $4 \mathrm{cn}$ model for the temperate broadleaf plant type used in this study $(\mathrm{clm} 4 \mathrm{cn}$, 52; clm4mod, 58; $\mu \mathrm{mol} \mathrm{m}^{-2} \mathrm{~s}^{-1}$ ).

\subsection{Simulations}

The $\mathrm{clm} 4 \mathrm{cn}$ and $\mathrm{clm} 4 \bmod$ models were used to simulate forest biogeochemistry at five sites in North American broadleaf temperate deciduous forests. The five sites were chosen based on the presence of long-term forest productivity measurements $(10+\mathrm{yr})$ and long-term $\mathrm{N}$ fertilization experiments $(10+y r)$, and are contained within the geographic boundaries of the analysis of forest inventory data by Thomas et al. (2010), which estimated how forest $C$ storage has responded to $\mathrm{N}$ deposition across the northeastern US (see below). Basic descriptions of the sites are included in Table 1. Four of the five sites were in Michigan, US, with each site receiving varying atmospheric deposition and a $3 \mathrm{~g} \mathrm{~N} \mathrm{~m}^{-2} \mathrm{yr}^{-1}$ experimental addition of $\mathrm{N}$ over ten years (Pregitzer et al., 2008; 1995-2005). The other site was at Harvard Forest in Massachusetts, US (Magill et al., 2004) and included two different $14 \mathrm{yr}$ fertilization additions ( 5 and $15 \mathrm{~g} \mathrm{~N} \mathrm{~m}^{-2} \mathrm{yr}^{-1}$; 
Table 2. Description of simulations and years of driver data used in each simulation.

\begin{tabular}{llll}
\hline Simulation* & N deposition & N fertilization & $\mathrm{CO}_{2}$ concentration \\
\hline (1) Control (baseline) & $1850-2004$ & None & $1850-2004$ \\
(2) Hold N deposition & 1850 & None & $1850-2004$ \\
(3) Elevated N deposition; & $1850-2004$; values & None & $1850-2004$ \\
EU N deposition gradient & $\begin{array}{l}\text { more similar to European } \\
\text { deposition levels }\end{array}$ & None & 1850 \\
& 1850 & None & 1850 \\
(4) Hold N deposition and $\mathrm{CO}_{2}$ & $1850-2004$ & Yrs. of field study, rate & $1850-2004$ \\
(5) Hold CO 2 & $1850-2004$ & of study (see Table 1) & \\
(6) N fertilization & & Yrs. of field study, & $1850-2004$ \\
(7) Non-N-limited & $1850-2004$ & rate necessary to & \\
& & match N demand & \\
\hline
\end{tabular}

* All simulations included transient land use with a harvest in the year that yields the observed stand age in 1994 (see Table 1).

1988-2002). All data used in this study for the five sites and six $\mathrm{N}$ fertilization experiments can be found in Magill et al. (2004) and Pregitzer et al. (2008). We simulated ecosystem response to transient $\mathrm{N}$ deposition and $\mathrm{N}$ fertilization at each of the five sites using the clm $4 \mathrm{cn}$ and clm 4 mod models (Table 2). The simulations involved running each model from 1850 to 2004 at each of the five sites with different combinations of forcing data (Table 2). The baseline (control; Table 2, Sim. 1) simulation used transient $\mathrm{N}$ deposition $\left(\mathrm{NH}_{\mathrm{x}}\right.$ and $\mathrm{NO}_{\mathrm{y}}$; Lamarque et al., 2005), atmospheric $\mathrm{CO}_{2}$, land use (by harvesting vegetation biomass in the year that yields the reported stand age at the five sites), and climate. $\mathrm{N}$ deposition and atmospheric $\mathrm{CO}_{2}$ trends had reconstructions covering the entire simulation (1850-2004). A $57 \mathrm{yr}$ meteorological dataset was available to force the model (1948-2004; Qian et al., 2006). We created site-level meteorological data by using the corresponding grid cell in the global gridded data (Qian et al., 2006). We used the data from 1948-1972 for the 1850-1972 simulation years, and the 1973-2004 meteorological dataset was used for the 1973-2004 simulation years (as in Randerson et al., 2009, and Bonan and Levis, 2010). Each simulation needed initial conditions that were attained by running the model to equilibrium using 1850 values for $\mathrm{N}$ deposition and atmospheric $\mathrm{CO}_{2}$ and the 1948-1972 time series for meteorological data. All wildfire was excluded in the spin-up and other simulations due to uncertainties using the statistical fire model at a single point location. Simulations used site-specific soil texture (Magill et al., 2004; Pregitzer et al., 2008). We refer to the equilibrium state used as initial conditions as the preindustrial steady state.

We isolated the influence of transient $\mathrm{N}$ deposition on $\mathrm{C}$ cycling at each site by repeating the baseline simulation described above except for holding $\mathrm{N}$ deposition constant at 1850 values (Table 2 , Sim. 2). We also tested whether $\mathrm{C}$ cycle sensitivity was different for larger inputs of $\mathrm{N}$ deposition than included in the baseline simulation (Table 2, Sim. 3). The higher $\mathrm{N}$ deposition simulation used $\mathrm{N}$ deposition values found in Western Europe and allowed us to explore why $\mathrm{N}$ deposition gradients in North America (Thomas et al., 2010) yielded steeper $\mathrm{C}$ responses than in Western Europe (de Vries et al., 2009). The high $\mathrm{N}$ deposition simulation used a $\mathrm{N}$ deposition trajectory from 1850 to 2004 with 1995-2004 mean deposition levels at the five sites of $2.2 \mathrm{~g} \mathrm{~N} \mathrm{~m}^{-2} \mathrm{yr}^{-1}$ (Table 1: EU deposition gradient) rather than the actual $\mathrm{N}$ deposition rates (1995-2004) at these sites that ranged from $0.68-1.18 \mathrm{~g} \mathrm{~N} \mathrm{~m}^{-2} \mathrm{yr}^{-1}$ (Table 1: US deposition gradient).

Because the NPP response to rising atmospheric $\mathrm{CO}_{2}$ is constrained by $\mathrm{N}$ availability, we tested whether the sensitivity of NPP to rising atmospheric $\mathrm{CO}_{2}$ changed as a result of the modifications to $\mathrm{clm} 4 \mathrm{cn}$. To test this sensitivity we performed two additional simulations at the five sites using the $\operatorname{clm} 4 \mathrm{cn}$ and $\mathrm{clm} 4 \mathrm{mod}$ : a simulation that held both $\mathrm{N}$ deposition and atmospheric $\mathrm{CO}_{2}$ constant at 1850 levels (Table 2, Sim. 4) and a simulation that held $\mathrm{CO}_{2}$ constant at 1850 levels but included 1850-2004 N deposition levels (Table 2, Sim. 5)

Finally, we simulated the six $\mathrm{N}$ fertilization experiments (Table 1; four sites with one experiment each and one site with two experiments) by adding $\mathrm{N}$ fertilization to the baseline simulation to best approximate the field experiments by specifying the start year, duration, magnitude and intraannual distribution of $\mathrm{N}$ application (Table 2, Sim. 6). To test whether the $\mathrm{N}$ fertilization treatments completely relieved $\mathrm{N}$ limitation, we simulated the six $\mathrm{N}$ fertilization experiments again, this time adding a very large dose of enough additional $\mathrm{N}$ to the fertilized treatment to meet any remaining $\mathrm{N}$ demand by plants and microbial immobilization ("non-Nlimited" treatment; Table 2, Sim. 7).

\section{4 $\mathrm{N}$ fertilization and deposition analysis and observations}

The model comparison to observations focused on NPP, net ecosystem productivity (NEP), and annual aboveground net 
Table 3. Model simulations and observations of the vegetation and ecosystem carbon increment response to nitrogen deposition and fertilization. Model uncertainty estimates correspond to variation among sites (1 S.E.). US = United States; EU = Europe.

\begin{tabular}{|c|c|c|c|c|c|c|}
\hline Response metric & $\begin{array}{l}\text { Carbon } \\
\text { measurement }\end{array}$ & Nitrogen input & $\begin{array}{l}\text { clm4cn } \\
\text { model }\end{array}$ & $\begin{array}{l}\text { clm4mod } \\
\text { model }\end{array}$ & Observations & Citation \\
\hline $\mathrm{dC}_{\mathrm{ACI}} / \mathrm{dN}_{\text {deposition }}$ & $\begin{array}{l}\text { Aboveground } \\
\text { carbon increment }\end{array}$ & $\begin{array}{l}\text { US deposition } \\
\text { gradient }\end{array}$ & $14.0 \pm 1.1$ & $34.2 \pm 3.0$ & $50(41-66)$ & Thomas et al. (2010) \\
\hline $\mathrm{dC}_{\mathrm{ACI}} / \mathrm{dN}_{\text {deposition }}$ & $\begin{array}{l}\text { Aboveground carbon } \\
\text { increment }\end{array}$ & $\begin{array}{l}\text { EU deposition } \\
\text { gradient }\end{array}$ & $11.8 \pm 0.8^{\mathrm{b}}$ & $26.2 \pm 2.6^{\mathrm{b}}$ & $15-40$ & DeVries et al. (2009) \\
\hline $\mathrm{dC}_{\mathrm{ACI}} / \mathrm{dN}_{\text {fertilization }}$ & $\begin{array}{l}\text { Aboveground carbon } \\
\text { increment }\end{array}$ & $\begin{array}{l}\text { Fertilization } \\
\text { experiments }\end{array}$ & $10.7 \pm 1.3$ & $10.6 \pm 4.5$ & $4 \pm 2.7$ & $\begin{array}{l}\text { Magill et al. (2004), } \\
\text { Pregitzer et al. (2008) }\end{array}$ \\
\hline $\mathrm{dC}_{\mathrm{NEP}} / \mathrm{dN}_{\text {deposition }}$ & $\begin{array}{l}\text { Net ecosystem } \\
\text { production }\end{array}$ & $\begin{array}{l}\text { US deposition } \\
\text { gradient }\end{array}$ & $30.0 \pm 1.8$ & $74.1 \pm 8.17$ & no data & \\
\hline $\mathrm{dC}_{\mathrm{NEP}} / \mathrm{dN}_{\text {deposition }}$ & $\begin{array}{l}\text { Net ecosystem } \\
\text { production }\end{array}$ & $\begin{array}{l}\text { EU deposition } \\
\text { gradient }\end{array}$ & $24.5 \pm 1.5^{\mathrm{b}}$ & $49.5 \pm 4.4^{b}$ & $50-75$ & Sutton et al. (2008) \\
\hline $\mathrm{dC}_{\mathrm{NEP}} / \mathrm{dN}_{\text {fertilization }}$ & $\begin{array}{l}\text { Net ecosystem } \\
\text { production }\end{array}$ & $\begin{array}{l}\text { Fertilization } \\
\text { experiments }\end{array}$ & $27.9 \pm 2.8$ & $23.2 \pm 9.4$ & $31 \pm 10$ & $\begin{array}{l}\text { Magill et al. (2004), } \\
\text { Pregitzer et al. (2008) }\end{array}$ \\
\hline
\end{tabular}

\footnotetext{
a The reported $61 \mathrm{dC} / \mathrm{dN}$ was divided by a factor of 1.23 to account for unmeasured nitrogen deposition. See Pinder et al. (2012) for more information.

$\mathrm{b}$ These model simulations used higher $\mathrm{N}$ deposition $\left(1994-2004\right.$ mean $\left.=2.2 \mathrm{~g} \mathrm{~N} \mathrm{~m}^{-2} \mathrm{yr}^{-1}\right)$ to approximate nitrogen deposition in regions that have experienced higher historical $\mathrm{N}$ deposition loads.
}

C increment (ACI) in plants because these were the variables measured in the $\mathrm{N}$ fertilization experiments and across the $\mathrm{N}$ deposition gradients. The model response to $\mathrm{N}$ fertilization was assessed by comparing mean annual aboveground NPP (ANPP) in the control and N-fertilized simulations to ANPP data from the corresponding control and fertilized treatments in the field data. In both the models and observations, ANPP corresponded to the sum of mean leaf and stem productivity over the course of the observational data. We also report ACI for the fertilization experiments (the change of aboveground C stock between years). ACI differs from NPP and ANPP in that ACI does not include the production and turnover of wood or leaves within a year that are included in NPP measurements. However, ACI includes the losses of $\mathrm{C}$ from mortality that are not included in NPP measurements. We report the ACI response to fertilization by dividing by the $\mathrm{N}$ added $\left(\mathrm{dC}_{\mathrm{ACI}} / \mathrm{dN}_{\text {fertilization }}\right)$.

We compared the model response to $\mathrm{N}$ deposition to observations from the literature. We calculated average ACI between 1994 and 2004 in the simulations with and without transient $\mathrm{N}$ deposition (both including transient $\mathrm{CO}_{2}$ ). The $\mathrm{ACI}$ response to $\mathrm{N}$ deposition was expressed as the ACI difference divided by the difference in mean $\mathrm{N}$ deposition over the same time period $\left(\mathrm{dC}_{\mathrm{ACI}} / \mathrm{dN}_{\text {deposition }}\right)$. We also report the difference in NEP divided by the difference in $\mathrm{N}$ deposition $\left(\mathrm{dC}_{\mathrm{NEP}} / \mathrm{dN}_{\text {deposition }}\right)$. We compared the above metrics of $\mathrm{N}$ deposition response to the corresponding metrics reported in analyses listed in Table 3.

We also assessed the contribution of $\mathrm{N}$ retention to the $\mathrm{N}$ deposition response in the $\mathrm{clm} 4 \mathrm{cn}$ and $\mathrm{clm} 4 \mathrm{mod}$ model. The total $\mathrm{N}$ deposition retained between 1970 and 2004 and between 2000 and 2004 was calculated to determine the longand short-term retention of $\mathrm{N}$ deposition, respectively. Over each time period, we calculated total deposition retained in the ecosystem and the fate of $\mathrm{N}$ deposition into soil organic matter (including litter and coarse woody debris) and vegetation.

In addition, we assessed the relative contribution of $\mathrm{CO}_{2}$ fertilization to how NPP responds to N deposition for each site using the method developed by Churkina et al. (2009) and Zaehle et al. (2010b). That is, we isolated the pure $\mathrm{N}$ deposition (i.e., $\mathrm{N}$ deposition enhancement without an interaction with $\mathrm{CO}_{2}$ fertilization), the pure $\mathrm{CO}_{2}$ fertilization, and the synergistic effect of $\mathrm{CO}_{2}$ fertilization and $\mathrm{N}$ deposition on NPP by calculating the mean NPP (1994-2004) in the simulations with (1) $\mathrm{N}$ deposition and atmospheric $\mathrm{CO}_{2}$ at preindustrial levels (Table 2, Sim. 4), (2) only transient $\mathrm{N}$ deposition $\left(\mathrm{CO}_{2}\right.$ at preindustrial levels; Table 2, Sim. 5), (3) only transient $\mathrm{CO}_{2}(\mathrm{~N}$ deposition at preindustrial levels; Table 2, Sim. 2), and (4) both transient $\mathrm{N}$ deposition and $\mathrm{CO}_{2}$ (i.e., control simulation described above; Table $2 \mathrm{Sim} 1$ ). The pure $\mathrm{N}$ deposition response was the difference in NPP between (1) and (2), while the pure $\mathrm{CO}_{2}$ fertilization response was the difference between (1) and (3). The additional NPP needed to reach the difference between (1) and (4) was the synergy between $\mathrm{N}$ deposition and $\mathrm{CO}_{2}$ fertilization.

\subsection{Sensitivity analysis to model structure}

We explored the sensitivity of the $\mathrm{N}$ deposition response $\left(\mathrm{dC}_{\mathrm{ACI}} / \mathrm{dN}_{\text {deposition }}\right)$ to the mechanisms and processes that differ between the $\operatorname{clm} 4 \mathrm{cn}$ and clm 4 mod models. We created intermediate models that sequentially step through the 15 model modifications that were included in the shift from the $\operatorname{clm} 4 \mathrm{cn}$ to the clm4mod (Table 4; Fig. 1). The sensitivity analysis was sequential in that each intermediate model in Table 4 includes all the modifications in the intermediate 
Table 4. Description of model modifications. Letters (a-1) refer to the processes shown in Fig. 1.

\begin{tabular}{|c|c|}
\hline Model & Model modifications \\
\hline Model 1 & Same as clm $4 \mathrm{cn}$. \\
\hline Model 2 & Decreased plant $\mathrm{N}$ uptake (d) by reducing the canopy photosynthesis (Bonan et al., 2011, 2012). \\
\hline Model 3 & Buffered the soil inorganic $\mathrm{N}$ available for immobilization (c) and plant $\mathrm{N}$ uptake (d). \\
\hline Model 4* & $\begin{array}{l}\text { Introduced a less open } \mathrm{N} \text { cycle by decreasing denitrification (f) and } \mathrm{N} \text { fixation (h). Maintains same } \\
\text { preindustrial steady state as model } 3 \text {. }\end{array}$ \\
\hline Model $5^{*}$ & $\begin{array}{l}\text { Decreased denitrification (f) to increase productivity to match preindustrial } \\
\text { steady state of the models } 5-15 \text {. Isolates the influence of higher baseline (preindustrial steady state) } \\
\text { primary productivity on the } \mathrm{N} \text { deposition response. }\end{array}$ \\
\hline Model $6^{*}$ & $\begin{array}{l}\text { Replaced (d) with a Michaelis-Menten approach to modeling plant } \mathrm{N} \text { uptake. } \mathrm{N} \text { uptake only occurs } \\
\text { when the plants are photosynthesizing. Adjusted (f) to maintain same preindustrial steady state } \\
\text { as models 5-15. }\end{array}$ \\
\hline Model 7 & $\begin{array}{l}\text { Same as model } 6 \text { except plant } N \text { uptake also occurs at night when plants are not photosynthesizing. } \\
\text { Adjusted (f) to maintain same preindustrial steady state as models } 5-15 \text {. }\end{array}$ \\
\hline Model 8* & $\begin{array}{l}\text { Altered immobilization (c) and plant } \mathrm{N} \text { uptake (d) by allowing immobilization to have first access } \\
\text { to soil inorganic } \mathrm{N} \text {. Adjusted (f) to maintain same preindustrial steady state as models } 5-15 \text {. }\end{array}$ \\
\hline Model 9 & $\begin{array}{l}\text { Added temperature and soil water limitations to denitrification (f). Adjusted (f) to maintain same } \\
\text { preindustrial steady state as models } 5-15 \text {. }\end{array}$ \\
\hline Model 10* & $\begin{array}{l}\text { Removed the } \mathrm{N} \text { gas loss }(\mathrm{g}) \text { that was proportional to net } \mathrm{N} \text { mineralization }(\mathrm{b}-\mathrm{c}) \text {. Adjusted }(\mathrm{f}) \text { to } \\
\text { maintain same preindustrial steady state as models } 5-15 \text {. }\end{array}$ \\
\hline Model 11* & $\begin{array}{l}\text { Added } \mathrm{NH}_{4}^{+} \text {and } \mathrm{NO}_{3}^{-} \text {pools; added nitrification (j). Adjusted (f) to maintain same preindustrial } \\
\text { steady state as models } 5-14 \text {. }\end{array}$ \\
\hline Model 12 & $\begin{array}{l}\text { Replaced temperature limitation of denitrification (f). Now proportional to heterotrophic respiration. } \\
\text { Adjusted (f) to maintain same preindustrial steady state as models } 5-15 \text {. }\end{array}$ \\
\hline Model 13 & $\begin{array}{l}\text { Added } \mathrm{N}_{2} \mathrm{O} \text { loss (k) that is proportional to nitrification (i). Adjusted (f) to maintain same preindustrial } \\
\text { steady state as models } 5-15 \text {. }\end{array}$ \\
\hline Model 14 & $\begin{array}{l}\text { Added dissolved organic } \mathrm{N} \text { leaching (l). Proportional to the turnover of lignin litter pool. Adjusted (f) } \\
\text { to maintain same preindustrial steady state as models } 5-15 \text {. }\end{array}$ \\
\hline $\begin{array}{l}\text { Model } 15 \\
(\operatorname{clm} 4 \mathrm{mod})\end{array}$ & $\begin{array}{l}\text { Added internal plant } \mathrm{N} \text { pool to buffer plant } \mathrm{N} \text { demand. Preindustrial steady state for the models } 5-14 \\
\text { are calibrated to match model } 15 \text {. Model } 15 \text { is equivalent to clm } 4 \text { mod. }\end{array}$ \\
\hline
\end{tabular}

* Denotes the model modifications that had the largest impact on the $\mathrm{N}$ deposition response $\left(>3 \mathrm{dC}_{\mathrm{ACI}} / \mathrm{dN}_{\mathrm{deposition}}\right)$. See Fig. 4 .

models listed above it. To quantify the influence of each process on the $\mathrm{N}$ deposition response, we ran simulations with and without transient $\mathrm{N}$ deposition using each of the intermediate models at a single site (Harvard Forest). The change in $\mathrm{dC}_{\mathrm{ACI}} / \mathrm{dN}_{\text {deposition }}$ associated with each modification was used to quantify the sensitivity of $\mathrm{N}$ deposition response to assumptions about the structure of the $\mathrm{C}$ and $\mathrm{N}$ cycles.

In most of the modifications, we were interested in the influence of the model structure on the $\mathrm{N}$ deposition response in the absence of altered baseline productivity (the preindustrial steady state; see Sect. 2.3). We manually adjusted the denitrification parameter to maintain the same baseline production so that Model 4 had the same baseline production (NPP and total C stocks) as Model 3, and Models 5-14 had the same baseline production as Model 15. To maintain the same baseline production, we altered the proportion of excess soil inorganic $\mathrm{N}$ (Models 4-10; Table 4) or $\mathrm{NO}_{3}^{-}$(Models 11-15; Table 4) that is denitrified. A detailed description of the intermediate models can be found in Appendix B.

\section{Results}

\subsection{Model response to $\mathbf{N}$ fertilization experiments}

The clm4mod model better predicted mean ANPP measured at the control plots at the five field sites (i.e., no additional $\mathrm{N}$ fertilization added) than the $\mathrm{clm} 4 \mathrm{cn}$ model. The mean observed ANPP across the five sites was $464 \pm 36 \mathrm{~g} \mathrm{C} \mathrm{m}^{-2} \mathrm{yr}^{-1}$ (1 S.E. across sites), while the mean in the clm $4 \bmod$ and clm $4 \mathrm{cn}$ model was $411 \pm 28$ and $352 \pm 50 \mathrm{~g} \mathrm{C} \mathrm{m}^{-2} \mathrm{yr}^{-1}$ (1 S.E.), respectively (Table 5). Both models predicted lower ANPP than observed in the most productive sites (MI-B, MI$\mathrm{C}$ and MI-D; Fig. 2). Neither model was consistently higher or lower than observed ANPP in the two least productive sites (HF and MI-A; Fig. 2a).

The clm4mod also better predicted both the mean ANPP in the $\mathrm{N}$ fertilized simulations and the increase in ANPP over the control simulation than the $\operatorname{clm} 4 \mathrm{cn}$. The fertilized ANPP in the clm 4 mod model $\left(474 \pm 8 \mathrm{~g} \mathrm{C} \mathrm{m}^{-2} \mathrm{yr}^{-1}\right)$ compared better to the observed fertilized ANPP in the six experiments at the five sites $\left(504 \pm 40 \mathrm{~g} \mathrm{C} \mathrm{m}^{-2} \mathrm{yr}^{-1}\right)$ than the 


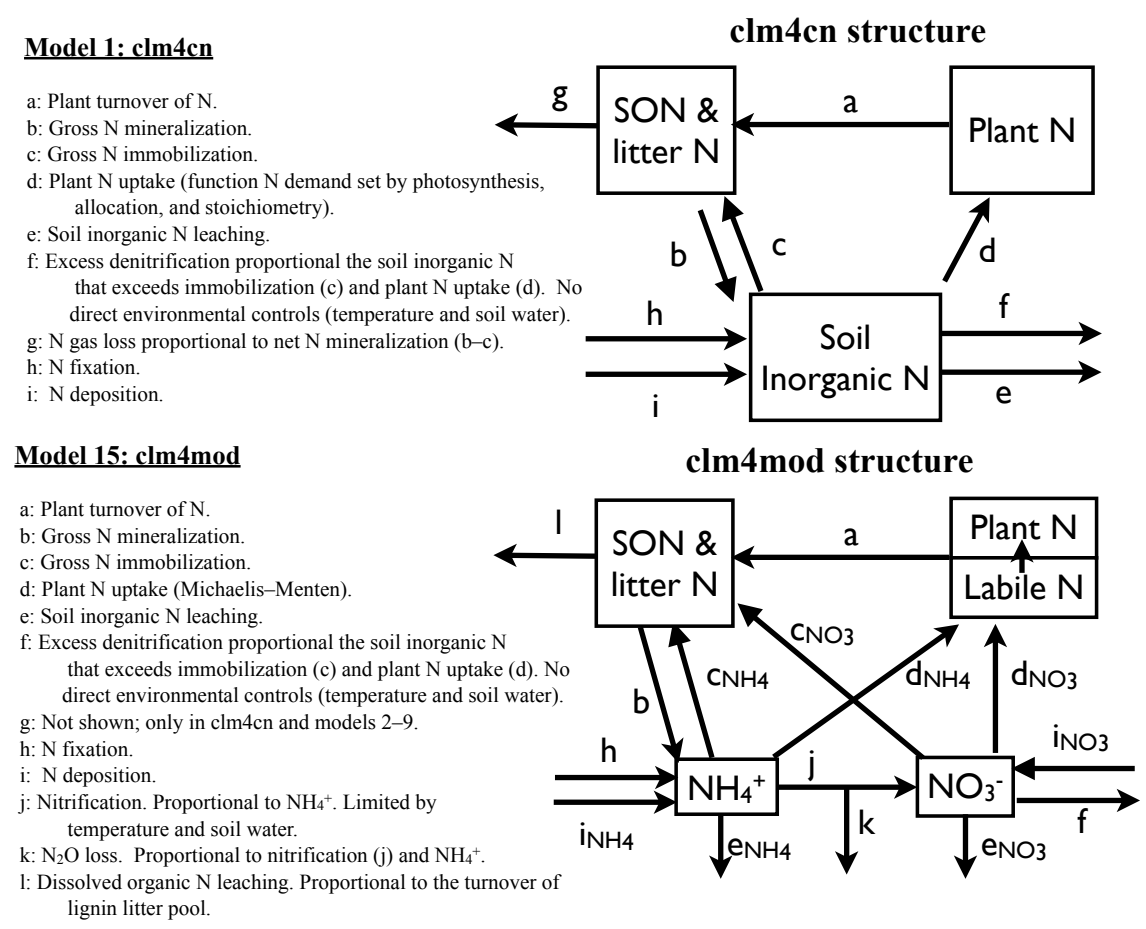

Fig. 1. Overview of the $\mathrm{clm} 4 \mathrm{cn}$ and $\mathrm{clm} 4 \mathrm{mod}$ model structure.

Table 5. Mean annual net primary productivity $\left(\mathrm{g} \mathrm{C} \mathrm{m}^{-2} \mathrm{yr}^{-1}\right)$ in the six nitrogen fertilization experiments at five temperate broadleaf deciduous forests. The field observations are compared to simulations from the clm $4 \mathrm{cn}$ model, and $\mathrm{clm} 4 \mathrm{mod}$ model. Error estimates correspond to variation among sites (1 S.E.).

\begin{tabular}{lccc}
\hline & Observations & clm4cn & clm4mod \\
\hline Control ANPP $(n=5)$ & $464 \pm 36$ & $352 \pm 50$ & $411 \pm 28$ \\
Fertilized ANPP $(n=6)$ & $504 \pm 40$ & $420 \pm 41$ & $474 \pm 8$ \\
$\Delta$ ANPP $(n=6) *$ & $55 \pm 8$ & $91 \pm 19$ & $57 \pm 18$ \\
Non-nitrogen-limited & Not & $742 \pm 10$ & $474 \pm 8$ \\
ANPP $(n=6)$ & measured & & \\
\hline
\end{tabular}

* The mean fertilization responses for the observations and model simulations were different than the difference between the mean control and mean fertilization ANPP because two experiments at Harvard Forest shared the same control treatment.

clm4cn model $\left(420 \pm 41 \mathrm{~g} \mathrm{C} \mathrm{m}^{-2} \mathrm{yr}^{-1}\right.$; Table 5). The mean increase in ANPP in the fertilization experiments was similar between the observations $\left(55 \pm 8 \mathrm{~g} \mathrm{C} \mathrm{m}^{-2} \mathrm{yr}^{-1}\right)$ and the clm4mod $\left(57 \pm 18 \mathrm{~g} \mathrm{C} \mathrm{m}^{-2} \mathrm{yr}^{-1}\right)$ with the clm4cn fertilization response $65 \%$ higher $\left(91 \pm 19 \mathrm{~g} \mathrm{C} \mathrm{m}^{-2} \mathrm{yr}^{-1}\right)$ than the observed response. At individual sites, the clm4mod corresponded substantially better to observations from the two $\mathrm{N}$ fertilization experiments at Harvard Forest than the clm $4 \mathrm{cn}$ (Fig. 2c). At the MI-A site, the clm4cn performed better compared to the observations than the clm4mod (Fig. 2c). Both the fertilization responses in the clm $4 \mathrm{cn}$ and clm4mod models were within the bounds of uncertainty in the observations at MI-B, MI-C, and MI-D (Fig. 2c).
Despite differences in ANPP response to $\mathrm{N}$ fertilization, both the clm4cn and clm4mod models predicted similar aboveground $\mathrm{C}$ increments per unit $\mathrm{N}$ fertilizer added $\left(\mathrm{dC}_{\mathrm{ACI}} / \mathrm{dN}_{\text {fertilizer }}\right.$; clm $4 \mathrm{cn}: 10.7 \pm 1.3 \mathrm{kgC}(\mathrm{kg} \mathrm{N})^{-1}$; clm4mod: $10.6 \pm 4.5 \mathrm{kgC}\left(\mathrm{kg} \mathrm{N}^{-1}\right)$ that were on average 1.5 times larger than the observed $\mathrm{dC}_{\mathrm{ACI}} / \mathrm{dN}_{\text {fertilizer }}$ $\left(4.0 \pm 2.7 \mathrm{~kg} \mathrm{C}(\mathrm{kg} \mathrm{N})^{-1}\right.$; Table 3$)$. However, the site-to-site variability in the clm 4 mod $\mathrm{dC}_{\mathrm{ACI}} / \mathrm{dN}_{\text {fertilizer }}$ was larger than the variability in clm $4 \mathrm{cn}$, leading to overlapping uncertainty with the observations. The mean annual net ecosystem production response to $\mathrm{N}$ fertilization $\left(\mathrm{dC}_{\mathrm{NEP}} / \mathrm{dN}_{\text {fertilizer }}\right)$ across all five sites was $27.9 \pm 2.8$ and $23.2 \pm 9.4 \mathrm{~kg} \mathrm{C}(\mathrm{kg} \mathrm{N})^{-1}$ for the clm $4 \mathrm{cn}$ and clm 4 mod models, respectively (Table 3 ). The clm $4 \mathrm{cn}$ compared better to the observed $\mathrm{d} \mathrm{C}_{\mathrm{NEP}} / \mathrm{dN}_{\text {fertilizer }}$ at the six fertilization experiments $\left(31 \pm 10 \mathrm{kgC}(\mathrm{kg} \mathrm{N})^{-1}\right.$; Table 3), although both models were contained in the observational uncertainty. Additionally, both net ecosystem production responses were within the uncertainty $\left(24 \pm 8.7 \mathrm{~kg} \mathrm{C}\left(\mathrm{kg} \mathrm{N}^{-1}\right)\right.$ reported by Lui and Greaver (2009) in a meta-analysis of forest NEP response to $\mathrm{N}$ fertilization.

\subsection{Model response to historical N deposition}

The clm4mod model had a $144 \%$ larger response of aboveground $\mathrm{C}$ increment to $\mathrm{N}$ deposition $\left(\mathrm{dC}_{\mathrm{ACI}} / \mathrm{dN}_{\text {deposition }}\right)$ than the clm $4 \mathrm{cn}$ model (Table 3 ). The $\mathrm{dC}_{\mathrm{ACI}} / \mathrm{dN}_{\text {deposition was }}$ 14.0 and $34.2 \mathrm{kgC}(\mathrm{kg} \mathrm{N})^{-1}$ in the clm4 $\mathrm{cn}$ and clm4mod models, respectively (Table 3 ). Both models predicted lower responses than reported for aboveground $\mathrm{C}$ increment 

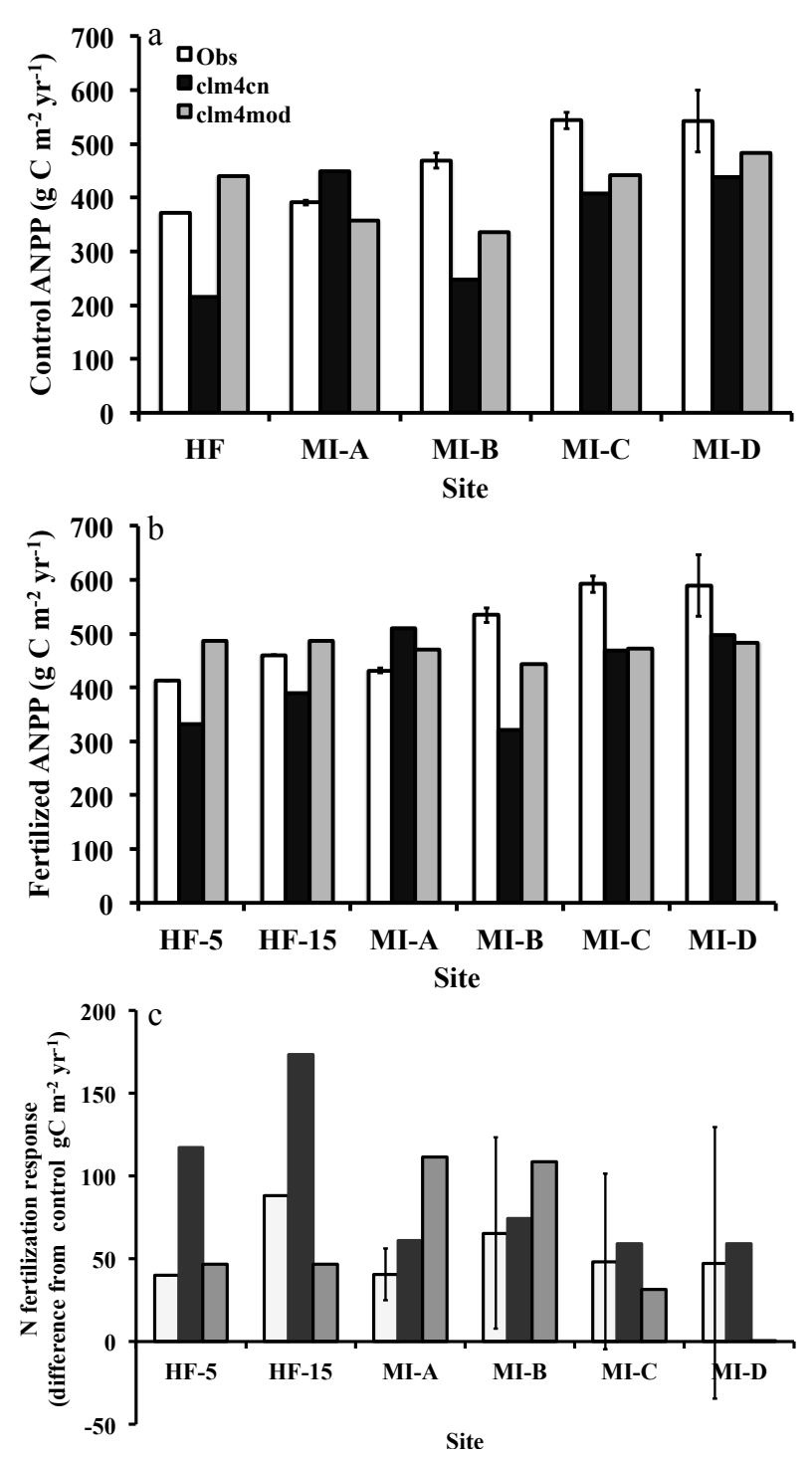

Fig. 2. Mean annual aboveground net primary production for the five temperate deciduous forests in Table 1. The measured values, clm4cn model predictions, and clm4mod model predictions are shown for (a) the control (non-fertilized) plots and (b) the nitrogen fertilized plots, along with (c) the differences between the control and fertilized treatments. The model simulations include transient nitrogen deposition, atmospheric $\mathrm{CO}_{2}$, and land use. Error bars represent the S.E. reported in Pregitzer et al. (2008).

across the northeastern US $\left(50 \mathrm{~kg} \mathrm{C}(\mathrm{kg} \mathrm{N})^{-1}\right.$; adjusted from Thomas et al., 2010 for higher rates of $\mathrm{N}$ deposition); however, the bias was substantially reduced in the clm $4 \mathrm{mod}$ model (Table 3).

In the simulations with higher rates of $\mathrm{N}$ deposition $\left(1995-2004\right.$ mean $\left.=2.2 \mathrm{~g} \mathrm{~N} \mathrm{~m}^{-2} \mathrm{yr}^{-1}\right)$, the aboveground $\mathrm{C}$ increment response to $\mathrm{N}$ deposition $\left(\mathrm{dC}_{\mathrm{ACI}} / \mathrm{dN}_{\text {deposition }}\right)$ decreased in both models (Table 3 ). The simulations with a large increase in $\mathrm{N}$ deposition were designed to test model sensitivity to $\mathrm{N}$ deposition levels larger than typically found in the US but similar to levels found in parts of Western Europe. Comparing the model results to observations from Western Europe, the mean $\mathrm{dC}_{\mathrm{ACI}} / \mathrm{dN}_{\text {deposition }}$ across all sites in the clm4mod model $\left(26.2 \mathrm{kgC}(\mathrm{kg} \mathrm{N})^{-1}\right)$ was contained within the range reported from inventory measurements of European forests across a $\mathrm{N}$ deposition gradient (Table 2; $15-40 \mathrm{~kg} \mathrm{C}\left(\mathrm{kg} \mathrm{N}^{-1}\right.$; de Vries et al., 2009), while the mean $\mathrm{clm} 4 \mathrm{cn}$ model result was lower than the reported range $\left(11.8 \mathrm{~kg} \mathrm{C}(\mathrm{kg} \mathrm{N})^{-1}\right)$.

For the NEP response to N, adding the belowground vegetation and soil response increased average $\mathrm{dC}$ NEP $/ \mathrm{dN}_{\text {deposition }}$ across the five sites to 30.0 and $74.1 \mathrm{~kg} \mathrm{C}(\mathrm{kg} \mathrm{N})^{-1}$ in the $\mathrm{clm} 4 \mathrm{cn}$ and $\mathrm{clm} 4 \mathrm{mod}$ models, respectively (Table 3 ). The $\mathrm{dC}_{\mathrm{NEP}} / \mathrm{dN}_{\text {deposition }}$ using the $\mathrm{EU} \mathrm{N}$ deposition values for the clm4mod model $\left(49.5 \mathrm{kgC}(\mathrm{kg} \mathrm{N})^{-1}\right)$ was within the range of values recalculated for European forest by Sutton et al. (2008; $\left.50-75 \mathrm{~kg} \mathrm{C}(\mathrm{kg} \mathrm{N})^{-1}\right)$ using eddy flux observations reported by Magnani et al. (2007). The mean $\mathrm{dC}_{\mathrm{NEP}} / \mathrm{dN}_{\text {deposition }}$ using the EU $\mathrm{N}$ deposition from the clm $4 \mathrm{cn}$ model $\left(24.5 \mathrm{~kg} \mathrm{C}(\mathrm{kg} \mathrm{N})^{-1}\right)$ was $50 \%$ less than the lower bound reported in Sutton et al. (2008).

\subsection{Mechanisms explaining the increased responsiveness of the modified model to $\mathrm{N}$ deposition and fertilization}

The mean retention of $\mathrm{N}$ deposition within the ecosystem was larger in clm4mod than $\mathrm{clm} 4 \mathrm{cn}$, mirroring the $\mathrm{dC}_{\mathrm{ACI}} / \mathrm{dN}_{\text {deposition }}$ response. Across all five sites, the mean retention of $\mathrm{N}$ deposition was higher in the clm4mod model than the $\mathrm{clm} 4 \mathrm{cn}$ model (Fig. 3). In both the $\mathrm{clm} 4 \mathrm{cn}$ and clm4mod, ecosystem $\mathrm{N}$ retention (Fig. 3; sum of $\mathrm{N}$ recovery in vegetation and soil) was lower when integrated over a $34 \mathrm{yr}$ period $(1970-2004: \operatorname{clm} 4 \mathrm{cn}=51 \%$; $\operatorname{clm} 4 \bmod =81 \%)$ than over a $4 \mathrm{yr}$ period $(2000-2004$ : $\operatorname{clm} 4 \mathrm{cn}=55 \%, \operatorname{clm} 4 \bmod =94 \%)$. The fate of $\mathrm{N}$ retained in the ecosystem was predominately in soil organic matter in both models and at both timescales (Fig. 3). However, the proportion of $\mathrm{N}$ deposition retained in both vegetation and soil was higher in the $\mathrm{clm} 4 \mathrm{mod}$ than the $\mathrm{clm} 4 \mathrm{cn}$ model (Fig. 3), with particularly large increases in $\mathrm{N}$ retained in soil.

The response to $\mathrm{N}$ deposition $\left(\mathrm{dC}_{\mathrm{ACI}} / \mathrm{dN}_{\text {deposition }}\right)$ was most sensitive to the use of a Michaelis-Menten approach to plant $\mathrm{N}$ uptake in the clm4mod that describes $\mathrm{N}$ uptake as a function of soil inorganic $\mathrm{N}$ and fine root $\mathrm{C}$, rather than the approach in $\mathrm{clm} 4 \mathrm{cn}$ that represents $\mathrm{N}$ uptake as a function of photosynthesis and the $\mathrm{N}$ required by stoichiometric constraints (Model 6; Table 3; Fig. 4). Implementing the Michaelis-Menten approach increased the $\mathrm{dC}_{\mathrm{ACI}} / \mathrm{dN}_{\text {deposition }}$ by $27 \mathrm{~kg} \mathrm{C}(\mathrm{kg} \mathrm{N})^{-1}$. The next largest sensitivity was associated with the pathway of N loss (Model 10; Table 4; Fig. 4); the removal of the $\mathrm{N}$ gas loss process simulated in $\mathrm{clm} 4 \mathrm{cn}$ as $1 \%$ of net $\mathrm{N}$ mineralization decreased the $\mathrm{dC}_{\mathrm{ACI}} / \mathrm{dN}_{\text {deposition }}$ by $15 \mathrm{~kg} \mathrm{C}(\mathrm{kg} \mathrm{N})^{-1}$ (Fig. 4). Because we increased the proportion of excess $\mathrm{N}$ that was denitrified to maintain the same 


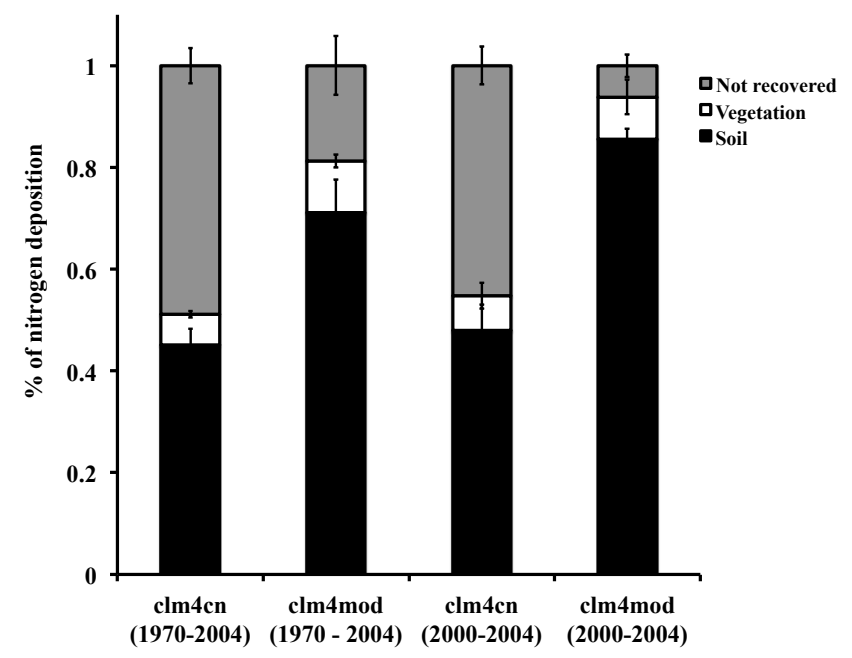

Fig. 3. Model predictions of ecosystem retention of nitrogen deposition, partitioned among soil organic matter and vegetation, averaged across all five sites for two time periods: 1970-2004 and 2000-2004. Error bars represent variation among sites (1 S.E.).

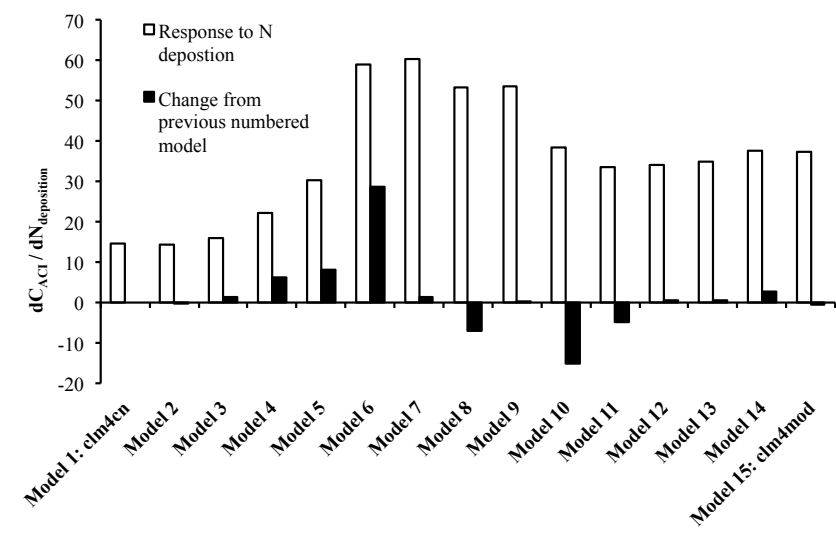

Sequential model modifications

Fig. 4. The sensitivity of the nitrogen deposition response to key changes in model structure for a single site (Harvard Forest). The figure shows the nitrogen deposition response, expressed as an annual aboveground carbon increment $\left(\mathrm{dC}_{\mathrm{ACI}} / \mathrm{dN}_{\mathrm{deposition}}\right)$ for the clm4cn model (Model 1), clm4mod (Model 15), and intermediary models (Model 2-14). Each model builds on the modifications in the previous models, and the difference in $\mathrm{dC}_{\mathrm{ACI}} / \mathrm{dN}_{\mathrm{deposition}}$ between a model and the previous model is shown in black. See Table 3 for a description of the mechanisms isolated in each model.

total $\mathrm{N}$ loss as at preindustrial steady state, the change in $\mathrm{dC}_{\mathrm{ACI}} / \mathrm{dN}_{\text {deposition }}$ was associated with modifying the particular pathways of $\mathrm{N}$ loss, rather than being associated with a modification to the total preindustrial $\mathrm{N}$ export.

The implementation of a less open $\mathrm{N}$ cycle with lower $\mathrm{N}$ input and outputs increased $\mathrm{dC}_{\mathrm{ACI}} / \mathrm{dN}_{\text {deposition }}$ by $6 \mathrm{~kg} \mathrm{C}(\mathrm{kg} \mathrm{N})^{-1}$ (Model 4; Table 4; Fig. 4). $\mathrm{dC}_{\mathrm{ACI}} / \mathrm{dN}_{\text {deposition }}$ increased by $8 \mathrm{kgC}(\mathrm{kg} \mathrm{N})^{-1}$ in the simulation that isolated the influence of reduced denitrification on the response to $\mathrm{N}$ deposition (Model 5; Table 4; Fig. 4). This simulation had the same preindustrial primary productivity as the simulation with Michaelis-Menten plant N uptake (Model 6) but without the Michaelis-Menten uptake mechanism (same model structure as Model 4 but with a lower denitrification parameter). In contrast, allowing microbial immobilization to have first access to soil inorganic N (Model 8; Fig. 1; Fig. 4) and implementing a representation of nitrification with separated $\mathrm{NH}_{4}^{+}$and $\mathrm{NO}_{3}^{-}$pools (Model 11; Table 4; Fig. 4) decreased $\mathrm{dC}_{\mathrm{ACI}} / \mathrm{dN}_{\text {deposition by }} 7$ and $5 \mathrm{~kg} \mathrm{C}(\mathrm{kg} \mathrm{N})^{-1}$, respectively. All other processes described in Table 4 had little impact on $\mathrm{dC}_{\mathrm{ACI}} / \mathrm{dN}_{\text {deposition }}\left(<3 \mathrm{~kg} \mathrm{C}(\mathrm{kg} \mathrm{N})^{-1}\right)$.

\subsection{Synergy between $\mathbf{N}$ deposition and atmospheric $\mathrm{CO}_{2}$}

Averaged across all five sites, the clm4mod and clm4cn models predicted similar increases in NPP over preindustrial NPP, attributed to the increase in both $\mathrm{N}$ deposition and atmospheric $\mathrm{CO}_{2}$ over the period from 1850 to $2004\left(\operatorname{clm} 4 \mathrm{cn}=84.1 \mathrm{~g} \mathrm{C} \mathrm{m}^{-2} \mathrm{yr}^{-1}\right.$; $\operatorname{clm} 4 \bmod =87.2 \mathrm{~g} \mathrm{C} \mathrm{m}^{-2} \mathrm{yr}^{-1}$; 1994-2004; Fig. 5b). However, the relative contribution of $\mathrm{N}$ deposition and $\mathrm{CO}_{2}$ fertilization differed strongly between the two models (Fig. 5a). The increase in NPP predicted by the clm $4 \mathrm{cn}$ model was comprised of a pure $\mathrm{N}$ deposition response $(46 \%)$ and a pure $\mathrm{CO}_{2}$ fertilization response $(57 \%)$ that were largely independent of each other, as the synergy only explained $7 \%$ of the NPP change (Fig. 5b). In contrast, the pure $\mathrm{CO}_{2}$ fertilization response in the clm4mod model was small $(12 \%)$ while the majority of the NPP increase was explained by a pure $\mathrm{N}$ deposition response $(58 \%)$ and a synergy between $\mathrm{N}$ deposition and rising $\mathrm{CO}_{2}(30 \%$; Fig. 5a).

\section{Discussion}

Overall, our modifications to the CLM-CN 4.0 substantially improved predictions of $\mathrm{C}$ storage in response to historical $\mathrm{N}$ deposition. The modifications in the clm4mod model increased the aboveground $\mathrm{C}$ increment response to historical $\mathrm{N}$ deposition by $144 \%$ compared to the clm $4 \mathrm{cn}$ model and compared more closely with observations across $\mathrm{N}$ deposition gradients in the northeastern US and Western Europe. Modifications to the representation of plant $\mathrm{N}$ uptake and pathways of $\mathrm{N}$ losses were the most important mechanisms that were responsible for the increased aboveground $\mathrm{C}$ increment response to $\mathrm{N}$ deposition in the clm 4 mod model. The net effect of the modifications increased ecosystem retention of $\mathrm{N}$ deposition and increased synergy between $\mathrm{N}$ deposition and fertilization from elevated atmospheric $\mathrm{CO}_{2}$. 


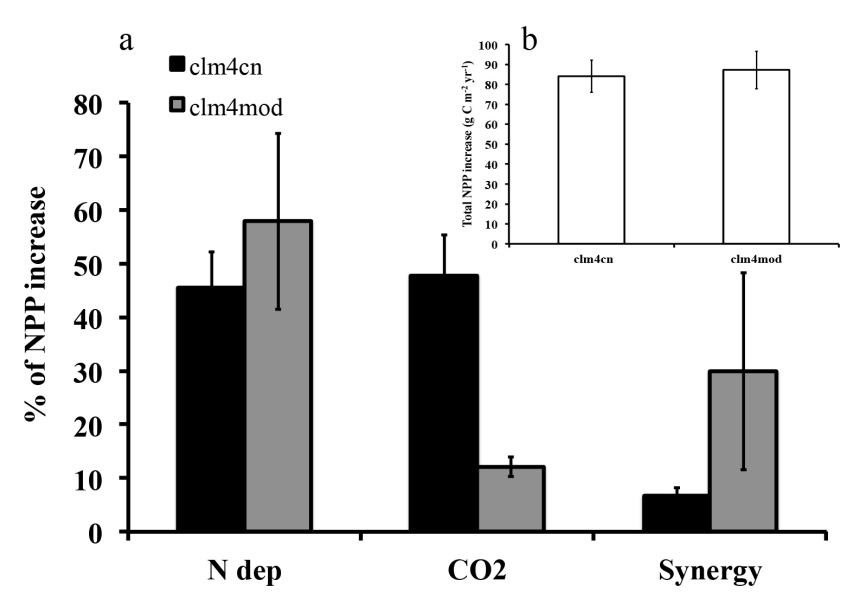

Fig. 5. Model predictions of net primary production (NPP) response to rising nitrogen deposition and atmospheric $\mathrm{CO}_{2}$ averaged across all five sites (a). The total NPP increase between 1850 and 2004 (b; in- set) is partitioned into the increase due only to nitrogen deposition, only to $\mathrm{CO}_{2}$ fertilization, and the synergy between nitrogen deposition and $\mathrm{CO}_{2}$ fertilization. Error bars represent variation among sites (1 S.E.).

\subsection{Response to historical $\mathbf{N}$ deposition}

The response to $\mathrm{N}$ deposition was most sensitive to the implementation of a Michaelis-Menten approach to plant $\mathrm{N}$ uptake (Model 6; Fig. 4). By adding the Michaelis-Menten uptake, plant $\mathrm{N}$ uptake depended on the fine root $\mathrm{C}$ stock, the soil inorganic $\mathrm{N}$ concentration, temperature, and $\mathrm{N}$ status of the plant rather than the $\mathrm{N}$ demand set by photosynthesis, allocation, and $\mathrm{C}: \mathrm{N}$ ratios of the allocated tissues. The Michaelis-Menten uptake increased the $\mathrm{N}$ deposition response by increasing $\mathrm{N}$ retention (2000-2004) by $9 \%$, likely due to greater ability of plants to compete against $\mathrm{N}$ loss processes. The increased $\mathrm{N}$ retention was also associated with a lower parameter value for the proportion of excess $\mathrm{N}$ lost as $\mathrm{N}$ gas in the model with Michaelis-Menten uptake (Model 6; Fig. 4). The lower parameter was necessary to yield the same steady state $\mathrm{N}$ gas loss at preindustrial conditions in the Michaelis-Menten uptake simulation because this approach to $\mathrm{N}$ uptake requires larger stocks of soil inorganic $\mathrm{N}$ to retain the same $\mathrm{N}$ uptake rate as a model without MichaelisMenten uptake. The lower $\mathrm{N}$ gas loss parameter likely allowed more $\mathrm{N}$ deposition to be retained in the ecosystem in the transient simulations. Michaelis-Menten uptake also increased soil inorganic $\mathrm{N}$ stocks necessary to yield the same $\mathrm{N}$ uptake as the clm $4 \mathrm{cn}$ model. This reduced the competition between plants and immobilization, thus increasing the total assimilation into $\mathrm{N}$ soil organic matter. A range of $\mathrm{N}$ uptake approaches are used in ecosystem and global biogeochemical models, suggesting the choice of how $\mathrm{N}$ uptake is represented can strongly influence the sensitivity to $\mathrm{N}$ deposition in the model.
The $\mathrm{N}$ deposition response was also sensitive to the pathway of $\mathrm{N}$ loss (Model 10; Fig. 4). Broadly there are two pathways of gas and leaching $\mathrm{N}$ loss used in ecosystem and global biogeochemical models: turnover-dependent and concentration-dependent pathways (Menge, 2011). Turnover dependent pathways refer to $\mathrm{N}$ losses that are proportional to the turnover of an internal nitrogen pool (i.e., litter N, soil organic N, or vegetation $\mathrm{N}$ ). Concentration-dependent pathways refer to $\mathrm{N}$ losses that are proportional to the concentration of soil inorganic $\mathrm{N}$ and typically only occur under periods of $\mathrm{N}$ saturation. As an example of a turnover-dependent pathway, the clm4cn has a pathway of $\mathrm{N}$ gas loss that is proportional to the net $\mathrm{N}$ mineralization associated with soil organic matter turnover (1\% of net $\mathrm{N}$ mineralization). The sensitivity analysis found that substituting a concentrationdependent pathway for a turnover-dependent gas loss pathway decreased the plant $\mathrm{C}$ response to $\mathrm{N}$ deposition; the substitution occurred through removing the $\mathrm{N}$ gas loss associated with net mineralization and compensating the reduced $\mathrm{N}$ loss by increasing denitrification of excess soil inorganic $\mathrm{N}$, a concentration-dependent pathway (Model 10; Fig. 4). Similarly, DON leaching in the clm4mod is another example of a turnover-dependent loss pathway (Menge, 2011) because it is modeled as proportional to the decomposition of litter. We found that by including DON leaching and reducing the denitrification of $\mathrm{NO}_{3}^{-}$(Model 14; Fig. 4), the plant $\mathrm{C}$ response to $\mathrm{N}$ deposition increased. Overall it is clear that models with a greater role of turnover-dependent $\mathrm{N}$ losses had a greater plant $\mathrm{C}$ response to $\mathrm{N}$ deposition than models with $\mathrm{N}$ loss dominated concentration-dependent pathways; We hypothesize that concentration-dependent pathways are able to more quickly lose $\mathrm{N}$ deposition when $\mathrm{N}$ availability is elevated, while turnover-dependent pathways increase $\mathrm{N}$ retention by requiring $\mathrm{N}$ deposition to cycle through the plants and soil before being lost.

Another important change to the CLM-CN that was responsible for increasing the $\mathrm{dC}_{\mathrm{ACI}} / \mathrm{dN}_{\text {deposition }}$ response in the clm4mod model was the implementation of a less open $\mathrm{N}$ cycle (Model 4; Fig. 4). N cycles range from being open to closed depending on the importance of the inputs and outputs of $\mathrm{N}$ relative to the internal $\mathrm{N}$-cycling fluxes. For example, at steady state in global biogeochemical models, all $\mathrm{N}$ fixation inputs are balanced by $\mathrm{N}$ losses from the ecosystem. As such, assuming equal stocks of $\mathrm{N}$, models with larger $\mathrm{N}$ inputs will have larger outputs at steady state, resulting in a faster and more open $\mathrm{N}$ cycle. The degree of openness of the $\mathrm{N}$ cycle in an ecosystem is not explicitly specified in ecosystem models; rather, it is controlled by the balance of $\mathrm{N}$ inputs to outputs. The magnitude and mechanisms governing $\mathrm{N}$ fixation and $\mathrm{N}$ losses vary widely among global biogeochemical models, likely indicating that the degree of openness of the $\mathrm{N}$ cycle also varies among models. Indeed, in comparison to another global biogeochemical model, in the extratropics the clm $4 \mathrm{cn}$ model reports both a greater role of $\mathrm{N}$ availability in the $\mathrm{C}$ cycle and greater $\mathrm{N}$ fixation (Thornton et al., 2007) than the 
LM3V model (Gerber et al., 2010). The LM3V model uses a demand-driven approach to $\mathrm{N}$ fixation that recognizes that $\mathrm{N}$ fixation is limited in closed-canopy temperate and boreal forests (Crews, 1999) rather than the relationship between NPP and N fixation, derived from Cleveland et al. (1999), used in the $\mathrm{clm} 4 \mathrm{cn}$.

The net effect of all the modifications (Models 2-15) was to increase the $\mathrm{dC}_{\mathrm{ACI}} / \mathrm{dN}_{\text {deposition }}$ response to $\mathrm{N}$ deposition by increasing the retention of $\mathrm{N}$ deposition within the ecosystem, as greater long-term $\mathrm{N}$ retention increased the availability of $\mathrm{N}$ to plants and allowed them to respond to rising atmospheric $\mathrm{CO}_{2}$. Retention of $\mathrm{N}$ deposition within the five simulated forests at the 4 to $30 \mathrm{yr}$ time horizon in the clm4mod model was between 81 and $95 \%$, and only 51 to $55 \%$ in the $\operatorname{clm} 4 \mathrm{cn}$ model. The higher $\mathrm{N}$ retention rate in the $\mathrm{clm} 4 \mathrm{mod}$ model than the $\mathrm{clm} 4 \mathrm{cn}$ model better matches observations from field tracer experiments in which isotopically labeled $\mathrm{N}\left({ }^{15} \mathrm{~N}\right)$ was added to forests and total isotope recovery was used to measure $\mathrm{N}$ retention (Nadelhoffer et al., 1999, 2004; Templer et al., 2012). At the Harvard Forest site, retention of added ${ }^{15} \mathrm{~N}$ in two experiments after $7 \mathrm{yr}$ ranged from 88 to $100 \%$, which compares well to clm4mod (Nadelhoffer et al., 2004; treatments with no additional $\mathrm{N}$ fertilization added). In contrast, a ${ }^{15} \mathrm{~N}$ tracer experiment at one of the Michigan sites (MI-B) only recovered $17.5 \%$ of added ${ }^{15} \mathrm{~N}$, which is substantially lower than both the clm $4 \mathrm{cn}$ and clm4mod models (Zak et al., 2004). This tracer study differed markedly from most others. That is, a meta-analysis of ${ }^{15} \mathrm{~N}$ experiments found that approximately $78 \%$ of added $\mathrm{N}$ was recovered in 11 temperate deciduous broadleaf forest ecosystems, and $75 \%$ was recovered across all forests (Templer et al., 2012). A similar analysis on nine sites, many of which were included in the meta-analysis conducted by Templer et al. (2012), found $90 \%$ recovery of ${ }^{15} \mathrm{~N}$ after $1-3 \mathrm{yr}$ of addition (Nadelhoffer et al., 1999). Overall, on the balance of evidence, the increased $\mathrm{N}$ retention in the clm4mod better reflects the ${ }^{15} \mathrm{~N}$ retention observed in most temperate forest tracer studies.

The net effect of all the modifications also increased synergy between $\mathrm{N}$ deposition and atmospheric $\mathrm{CO}_{2}$ in the clm4mod. Surprisingly, when averaged across all five sites, the increase in NPP resulting from $\mathrm{N}$ deposition was similar between the two models in the simulations when rising atmospheric $\mathrm{CO}_{2}$ was not included (Fig. 5b). However, when rising atmospheric $\mathrm{CO}_{2}$ was included, the synergy between $\mathrm{N}$ deposition and $\mathrm{CO}_{2}$ led to a larger total response to $\mathrm{N}$ deposition in the clm4mod model than in the $\mathrm{clm} 4 \mathrm{cn}$ model. This increase in synergy was due to the greater retention of $\mathrm{N}$ deposition in the $\mathrm{clm} 4 \mathrm{mod}$ than the $\mathrm{clm} 4 \mathrm{cn}$ model. The reduction of $\mathrm{N}$ limitation resulting from the additional ecosystem $\mathrm{N}$ allowed an enhancement of photosynthesis by the next most limiting resource in the model, $\mathrm{CO}_{2}$, whereas the clm $4 \mathrm{cn}$ model remained $\mathrm{N}$ limited. Consequently, the clm4mod model exhibited $\mathrm{CO}_{2}$ fertilization in the simulation with both rising $\mathrm{CO}_{2}$ and $\mathrm{N}$ deposition, enabled in part by rising $\mathrm{N}$ deposition. Overall, the increased enhancement of NPP due to synergy between $\mathrm{N}$ deposition and $\mathrm{CO}_{2}$ from $7 \%$ in $\mathrm{clm} 4 \mathrm{cn}$ to $30 \%$ in clm $4 \mathrm{mod}$ led to better correspondence with other studies - a $25 \%$ synergistic effect measured in a field-based $\mathrm{CO}_{2}$ fertilization experiment of needleleaf pine forest (Oren et al., 2001) and a $28 \%$ synergistic effect reported by a global modeling analysis using BIOME-BGC model (Churkina et al., 2009). It is important to note that the sites used in the analysis were not in arid environments where soil moisture can regulate $\mathrm{N}$ limitation and $\mathrm{CO}_{2}$ fertilization (Felzer et al., 2011). Future studies can expand the analysis beyond temperature deciduous forests and explore how the set of model modifications influences $\mathrm{C}-\mathrm{N}$ interactions in a range of ecosystem types.

\subsection{Response to $\mathbf{N}$ fertilization}

Overall, the clm4mod either improved or had no impact on the comparison to observations from $\mathrm{N}$ fertilization experiments, depending on the metric used in the model evaluation. In this study, we used three metrics to compare model predictions from clm $4 \mathrm{cn}$ and $\mathrm{clm} 4 \mathrm{mod}$ to $\mathrm{N}$ fertilization experiments, with each metric testing different aspects of model representation of $\mathrm{N}$ limitation. The first metric, the increase of ANPP in response to $\mathrm{N}$ fertilization, tested the productivity response, particularly wood and leaf production, to $\mathrm{N}$ fertilization. The ANPP response metric showed that, on average, the clm4mod corresponded better to observations than the $\mathrm{clm} 4 \mathrm{cn}$, with particular improvements at the Harvard Forest site. The improved correspondence at the Harvard Forest site was attributable to both a decrease in potential ANPP when $\mathrm{N}$ was not limiting (see discussion below) and an increase in the ANPP of the control treatment.

However, the ANPP increase metric did not include changes in mortality that were included in the second metric, $\mathrm{dC}_{\mathrm{ACI}} / \mathrm{dN}_{\text {fertilization }}$ (i.e., the change in standing stock of aboveground $\mathrm{C}$ between years). The model modifications did not have an impact on the mean $\mathrm{d} \mathrm{C}_{\mathrm{ACI}} / \mathrm{dN}_{\text {fertilization }}$ response to $\mathrm{N}$ fertilization and both the clm4mod and clm $4 \mathrm{cn}$ predicted larger $\mathrm{dC}_{\mathrm{ACI}} / \mathrm{dN}_{\text {fertilization }}$ than observed. The two key differences between the ANPP responses and $\mathrm{dC}_{\mathrm{ACI}} / \mathrm{dN}_{\text {fertilization }}$ to fertilization were (1) increased mortality from $\mathrm{N}$ fertilization in the field studies may not decrease ANPP but will decrease $\mathrm{dC} / \mathrm{dN}$, and (2) increased foliar production in the models increases ANPP without directly increasing $\mathrm{dC} / \mathrm{dN}$. Neither model included mechanisms through which elevated $\mathrm{N}$ inputs could increase tree mortality and tissue turnover, and both models predicted an increase in foliar productivity not found in the fertilization experiments (Magill et al., 2004; Pregitzer et al., 2008).

The productivity of the $\mathrm{N}$ fertilized treatment alone is the third metric describing how productivity responded to $\mathrm{N}$ fertilization. The ANPP in the field fertilized plots can be viewed as an approximation of the $\mathrm{N}$ unlimited productivity, assuming the fertilization level was high enough to meet 
plant demand and low enough to prevent negative effects of soil acidification. If so, the measure of $\mathrm{N}$ unlimited productivity is a metric that does not test the model response to $\mathrm{N}$ per se; rather, it tests the representation of the next most limiting resource in the models. Averaged across all six fertilization experiments, the clm4mod model did improve predictions of ANPP in the fertilized treatment. Higher ANPP in the fertilization treatments in the clm4mod model than the clm $4 \mathrm{cn}$ model was surprising because the $\mathrm{clm} 4 \bmod$ model included changes to the CLM-CN 4.0, described in Bonan et al. (2012), that decreased canopy level photosynthesis. Therefore, including the modifications that lowered photosynthesis should have decreased the simulated productivity when $\mathrm{N}$ limitation was relieved. However, a key difference between the $\mathrm{clm} 4 \mathrm{cn}$ and $\mathrm{clm} 4 \bmod$ models was that the simulated $\mathrm{N}$ fertilization experiments relieved $\mathrm{N}$ limitation in the clm4mod simulations while it did not in the clm $4 \mathrm{cn}$ simulations, potentially due to the high ecosystem retention of $\mathrm{N}$ in the clm4mod. Table 4 shows that the $\mathrm{N}$ unlimited ANPP in the clm4mod did not differ from the ANPP in the fertilization simulations, while the N unlimited ANPP in the $\operatorname{clm} 4 \mathrm{cn}$ was $77 \%$ greater than the ANPP in the fertilization simulations. The low ecosystem retention of $\mathrm{N}$ in the $\mathrm{clm} 4 \mathrm{cn}$ model maintained $\mathrm{N}$ limitation even at fertilization levels over double net $\mathrm{N}$ mineralization rates.

One important caveat when using $\mathrm{N}$ fertilization studies to evaluate $\mathrm{C}-\mathrm{N}$ interactions in models is accounting for potential harmful affects of fertilization-induced inorganic $\mathrm{N}$ leaching on base cation exchange and forest health (i.e., Hogberg et al., 2007; Wallace et al., 2007). The clm4mod simulates greater inorganic $\mathrm{N}$ leaching than the $\mathrm{clm} 4 \mathrm{cn}(\mathrm{Ta}-$ ble A2). This increase in leached $\mathrm{N}$ would likely lead to greater cation depletion and acidification. However, neither clm $4 \mathrm{cn}$ nor clm4mod simulates other element cycles, such as calcium and aluminum, nor links between soil solution chemistry and growth or mortality needed to mechanistically represent the negative impacts of $\mathrm{N}$ leaching on forest productivity and tree survival. While some $\mathrm{N}$ fertilization studies across the northeast US have reported harmful impacts of $\mathrm{N}$ fertilization (e.g., Wallace et al., 2007; Magill et al., 2004 - Pine site; McNulty et al., 2005), all of the studies used in this analysis yielded neutral or positive effects of fertilization on ANPP and C accumulation (Magill et al., 2004; Pregitzer et al., 2008).

\subsection{Implications}

The set of model simulations presented in this study also provides insight into the observational data. The reported $\mathrm{dC} / \mathrm{dN}$ was lower for the fertilization experiments than for the $\mathrm{dC} / \mathrm{dN}$ from $\mathrm{N}$ deposition gradients (Table 3). Furthermore, there was a lower reported $\mathrm{dC} / \mathrm{dN}$ in gradient studies in Europe than in the US (Table 3). Despite these disparities, we show that the reported $\mathrm{dC} / \mathrm{dN}$ data are reconcilable if the differences in the magnitude and timescale of $\mathrm{N}$ additions are considered. The clm4mod model simulations overlapped or were near the uncertainty bounds in the observations across the different time scales and magnitudes of $\mathrm{N}$ additions. The $\mathrm{N}$ deposition gradient studies measured the response to lower $\mathrm{N}$ inputs over a longer period of time (decades to a century), while the $\mathrm{N}$ fertilization experiments measured the response to higher inputs over a shorter timescale (years to decades). This indicates that the differences in ecosystem $\mathrm{N}$ use efficiencies reported for different fertilization studies and $\mathrm{N}$ deposition gradients may be explained by differences in the magnitude and timescale of $\mathrm{N}$ addition.

Overall, the substantial increase in C storage response to $\mathrm{N}$ deposition that occurred as a result of modifications to the CLM-CN 4.0 model resulted in a better comparison to observations of temperate broadleaf forest growth across $\mathrm{N}$ deposition gradients and to $\mathrm{N}$ fertilization experiments. The improved sensitivity to $\mathrm{N}$ inputs was driven primary by altering the mechanisms governing plant $\mathrm{N}$ uptake and the pathways of $\mathrm{N}$ loss. At the global scale, the modifications to CLM-CN presented are likely to improve the model correspondence to the globally distributed set of $\mathrm{N}$ fertilization experiments, ${ }^{15} \mathrm{~N}$ tracer studies, and small catchment $\mathrm{N}$ budgets that have been previously used to benchmark global biogeochemical models (Thomas et al., 2013). Furthermore, we show that due to non-linearity in ecosystem response to $\mathrm{N}$ addition, testing models with both the response to gradual increases in $\mathrm{N}$ inputs over decades ( $\mathrm{N}$ deposition) and $\mathrm{N}$ pulse additions of $\mathrm{N}$ over multiple years ( $\mathrm{N}$ fertilization) allows for greater understanding of the mechanisms governing $\mathrm{C}-\mathrm{N}$ coupling.

\section{Appendix A}

\section{clm4mod model description}

The clm4mod model includes changes to the canopy scaling of photosynthesis, maximum photosynthetic rates, radiative transfer, leaf photosynthesis, and stomatal conductance described in Bonan et al. $(2012,2011)$. Additional modifications are described below.

\section{A1 Nitrogen uptake by plants}

Plant uptake of inorganic nitrogen (N) in CLM-CN 4.0 ( $\operatorname{clm} 4 \mathrm{cn}$ ) is based on the $\mathrm{N}$ required to match the demand set by $\mathrm{N}$ unlimited photosynthesis (i.e., potential gross primary productivity) and plant tissue $\mathrm{C}: \mathrm{N}$ stoichiometric constraints. In the clm $4 \mathrm{cn}$ model, $\mathrm{N}$ uptake is independent of allocation to fine root mass. The clm4mod model represents $\mathrm{N}$ uptake as a function of fine root carbon $(\mathrm{C})$, mass $\left(\mathrm{C}_{\text {froot }}\right)$, soil inorganic $\mathrm{N}$ availability $\left(\mathrm{NH}_{4}\right.$, av $\mathrm{NO}_{3}$, av $)$, soil temperature $(f(T))$, and plant demand for $\mathrm{N}\left(f\left(\mathrm{~N}_{\text {labile }}\right)\right)$.

$$
\begin{aligned}
U_{\mathrm{N}, \text { plant }}= & V_{\text {nmax }} \frac{\mathrm{NH}_{4, \text { av }}+\mathrm{NO}_{3, \text { av }}}{\left(\mathrm{NH}_{4, \text { av }}+\mathrm{NO}_{3, \text { av }}\right)+K_{\text {min }}} \\
& \mathrm{C}_{\text {froot }} f\left(\mathrm{~N}_{\text {labile }}\right) f(T),
\end{aligned}
$$


Table A1. New parameters introduced to the CLM-CN 4.0.

\begin{tabular}{|c|c|c|c|c|}
\hline Parameter & Value & Units & Description & Reference \\
\hline$V_{\text {nmax }}$ & $2.7 \times 10^{-8}$ & $\mathrm{~g} \mathrm{Ng} \mathrm{C}^{-1} \mathrm{~s}^{-1}$ & Maximum $\mathrm{N}$ uptake per unit fine root $\mathrm{C}$ at $25^{\circ} \mathrm{C}$ & None \\
\hline$K_{\min }$ & 1 & $\mathrm{~g} \mathrm{~N} \mathrm{~m}^{-2}$ & Half saturation constant for plant nitrogen uptake & Yang et al. (2010) \\
\hline$x$ & 1 & Proportion & Proportion of $1 \mathrm{yr}$ worth of live tissue nitrogen turnover & Gerber et al. (2010) \\
\hline$b_{\mathrm{NH}_{4}}$ & 0.10 & Proportion & $\begin{array}{l}\text { Proportion of soil } \mathrm{NH}_{4}^{+} \text {available for plant uptake, } \\
\text { immobilization and loss processed }\end{array}$ & Gerber et al. (2010) \\
\hline$b_{\mathrm{NO}_{3}}$ & 1 & Proportion & $\begin{array}{l}\text { Proportion of soil } \mathrm{NO}_{3}^{-} \text {available for plant uptake, } \\
\text { immobilization and loss processed }\end{array}$ & Gerber et al. (2010) \\
\hline$b_{\text {nlabile }}$ & 0.02 & Proportion & $\begin{array}{l}\text { Proportion of plant labile nitrogen available to build } \\
\text { tissue per } 30 \text { min time step }\end{array}$ & None \\
\hline$K_{\text {nitr1 }}$ & 0.2 & Proportion & Proportion of net mineralization that nitrified & Parton et al. (2001) \\
\hline$K_{\text {nitr2 }}$ & 0.1 & $\mathrm{day}^{-1}$ & Maximum Proportion of available $\mathrm{NH}_{4}^{+}$nitrified & Parton et al. (2001) \\
\hline$K_{\mathrm{N}_{2} \mathrm{O}}$ & 0.02 & Proportion & Proportion of nitrification lost as $\mathrm{N}_{2} \mathrm{O}$ & Parton et al. (2001) \\
\hline$D$ & 0.05 & $\mathrm{~g} \mathrm{C}^{-1}$ & Maximum denitrification rate per $\mathrm{g}$ of soil respiration & Bradbury et al. (1993) \\
\hline$p_{\text {DOM }}$ & 0.015 & Proportion & $\begin{array}{l}\text { Proportion of litter mass transferred from litter } 3 \\
\text { pool to soil } 3 \text { pool that produces dissolved organic carbon } \\
\text { and nitrogen }\end{array}$ & Gerber et al. (2010) \\
\hline
\end{tabular}

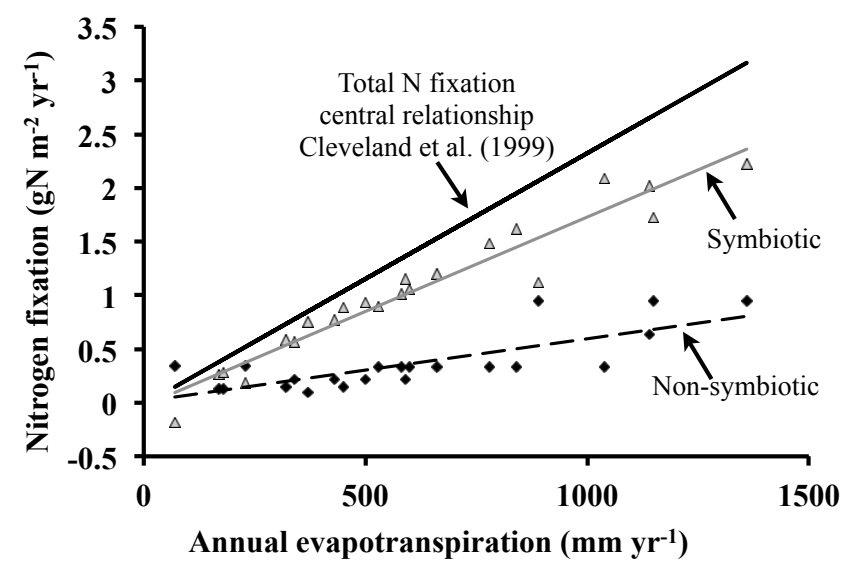

Fig. A1. The relationship between total, symbiotic and nonsymbiotic nitrogen fixation and annual evapotranspiration. Data are from Cleveland et al. (1999). The relationship for total fixation is from the central $\mathrm{N}$ fixation line in Fig. 1 of Cleveland et al. (1999).

where $f\left(\mathrm{~N}_{\text {labile }}\right)$ down regulates the uptake capacity based on the stock of labile $\mathrm{N}$ in the plant. As $\mathrm{N}_{\text {labile }}$ approaches one year's worth of $\mathrm{N}$ turnover of live tissue ( $x$; leaves, fine roots, and live wood), the maximum uptake capacity decreases. The down regulation function is based on Aber et al. (1997).

$f\left(\mathrm{~N}_{\text {labile }}\right)=\sqrt{1-\frac{\mathrm{N}_{\text {labile }}}{x}}$

The temperature function $f(T)$, is the same function governing soil decomposition, nitrification (see below), and denitrification (see below). $\mathrm{NH}_{4}$, av $\mathrm{NO}_{3}$, av are the concentrations of ammonium and nitrate that are available for plant uptake (see below). $V_{\text {nmax }}$ is the maximum uptake capacity
Table A2. Mean simulated preindustrial nitrogen fluxes $\left(\mathrm{g} \mathrm{N} \mathrm{m}^{-2} \mathrm{yr}^{-1}\right)$ averaged across all five sites in Table 1 ( \pm 1 S.E.).

\begin{tabular}{lcc}
\hline Flux & clm4cn & clm4mod \\
\hline Nitrogen fixation & $1.3 \pm 0.1$ & $0.26 \pm 0.01$ \\
Nitrogen deposition & $0.15 \pm 0.01$ & $0.15 \pm 0.01$ \\
Nitrogen gas loss & $1.4 \pm 0.1$ & $0.26 \pm 0.01$ \\
Mineral nitrogen leaching & $0 \pm 0$ & $0.07 \pm 0.01$ \\
DON leaching & $\mathrm{NA}$ & $0.1 \pm 0.004$ \\
Plant nitrogen uptake & $6.2 \pm 0.67$ & $6.9 \pm 0.29$ \\
Net nitrogen mineralization & $6.1 \pm 0.66$ & $6.5 \pm 0.25$ \\
Nitrification & $\mathrm{NA}$ & $3.6 \pm 0.06$ \\
\hline
\end{tabular}

at $25^{\circ} \mathrm{C}$ when $\mathrm{N}$ demand is large (i.e., $\left.f\left(\mathrm{~N}_{\text {labile }}\right)=1\right) . K_{\min }$ is the half saturation constant for plant uptake.

The availability of $\mathrm{N}$ within the plant for growth is buffered so that a proportion $(2 \%)$ of the labile $\mathrm{N}$ pool is available to build plant tissue.

\section{A2 Fine root turnover}

In the clm $4 \mathrm{cn}$ model, the turnover of fine root $\mathrm{C}$ is linked to the turnover of leaf $\mathrm{C}$. In the clm4mod version, the root turnover is an explicit parameter and is decoupled from leaf turnover. Root turnover occurs throughout the year, rather than only when leaves senescence. Root turnover is maintained at the same rate as the $\operatorname{clm} 4 \mathrm{cn}$ model for all species $\left(1.0 \mathrm{yr}^{-1}\right)$, except boreal and temperate needleleaf species, which have a turnover of $0.3 \mathrm{yr}^{-1}$ based on White et al. (2000). Decoupling fine root turnover from leaf turnover allows fine roots to be present throughout the year and permits a fast response of plant $\mathrm{N}$ uptake in the spring. 


\section{A3 Soil N dynamics}

The clm4mod version of the model includes soil inorganic pools of $\mathrm{NH}_{4}^{+}$and $\mathrm{NO}_{3}^{-}$, rather than a single inorganic $\mathrm{N}$ pool, as implemented in the clm $4 \mathrm{cn}$ model. $\mathrm{The}^{\mathrm{NH}_{4}^{+}}$pool is buffered to represent an exchangeable pool and a pool in solution that is available for plants, immobilization, nitrification, and leaching.

$\mathrm{NH}_{4, \text { av }}=b_{\mathrm{NH}_{4}} \mathrm{NH}_{4}^{+}$,

where $b_{\mathrm{NH}_{4}}$ is assumed to be $10 \%$ of total soil $\mathrm{NH}_{4}^{+}$(Gerber et al., 2010). Constant buffering capacity is a first approximation for a more complex process of resorption/desorption. Future model development could parameterize non-linearity into the buffering capacity that is a function of the total soil organic matter and the bulk density of the soil. $\mathrm{NO}_{3}^{-}$is assumed to have no buffering capacity in the soil, therefore

$\mathrm{NO}_{3, \text { av }}=\mathrm{NO}_{3}^{-}$.

\section{A4 Internal N cycling}

The clm4mod model assumes that microbes have priority for soil inorganic $\mathrm{N}$ to meet the immobilization demand. Plant uptake and immobilization of $\mathrm{N}$ is divided between $\mathrm{NH}_{4}^{+}$ and $\mathrm{NO}_{3}^{-}$in proportion to the availability of each $\mathrm{N}$ species $\left(\mathrm{NH}_{4, \text { av }} ; \mathrm{NO}_{3, \text { av }}\right.$ ). The conversion of $\mathrm{NH}_{4}^{+}$to $\mathrm{NO}_{3}^{-}$(nitrification) is represented as a function of net $\mathrm{N}$ mineralization, $\mathrm{NH}_{4}^{+}$availability, temperature, and water availability based on Parton et al. (2001). Nitrifiers are assumed to be less competitive for $\mathrm{NH}_{4}^{+}$than plants and immobilization into soil organic matter.

$\mathrm{N}_{\text {nitr }}=K_{\text {nitr1 }} \mathrm{N}_{\text {mineralization }}+K_{\text {nitri2 }} \mathrm{NH}_{\mathrm{av}, \text { nitr }} f(T) f(W)$

where the $\mathrm{NH}_{4}$, av nitr is the $\mathrm{NH}_{4}^{+}$available for nitrification,

$\mathrm{NH}_{4, \text { av, nitr }}=\mathrm{NH}_{4, \text { av }}-U_{\mathrm{NH}_{4, \text { plant }}}-U_{\mathrm{NH}_{4, \text { soil }}}$,

and $K_{\text {nitr1 }}, K_{\text {nitr2 }}, f(T)$, and $f(W)$ are the proportion of net mineralization that is nitrified, the maximum nitrification rate $\left(\mathrm{s}^{-1}\right)$ based on available $\mathrm{NH}_{4}$, av, nitr, the temperature modifier, and the water availability modifier, respectively. $f(T)$ and $f(W)$ are the same temperature and water functions that modified decomposition and plant $\mathrm{N}$ uptake (Thornton et al., 2007, 2009). The clm 4 mod model ignores the effect of $\mathrm{pH}$ on nitrification (Parton et al., 2001). A proportion (0.02) of the nitrification is lost to $\mathrm{N}_{2} \mathrm{O}$ and not converted to $\mathrm{NO}_{3}^{-}$(Parton et al., 2001).

\section{A5 Inorganic $\mathrm{N}$ loss}

In the clm4mod model, the leaching of $\mathrm{NH}_{4}^{+}$is a function of the soil water drainage and $\mathrm{NH}_{4}$, av , minus the $\mathrm{NH}_{4}^{+}$uptake by plants, immobilization, and nitrifiers during the model time step. Likewise, the leaching of $\mathrm{NO}_{3}^{-}$is a function of the soil water drainage and $\mathrm{NO}_{3}^{-}$, minus the $\mathrm{NO}_{3}^{-}$taken up by plants and immobilization during the model time step.

The loss of $\mathrm{NO}_{3}^{-}$through denitrification is modeled as a function of the available nitrate $\mathrm{NO}_{3}$, av (minus nitrate uptake by plants, immobilization, and leaching), the ratio of soil water to saturated soil water, and total respiration from soil organic matter decomposition (a proxy for microbial activity and oxygen composition; $\mathrm{CO}_{2}$, soil). The representation is described in Bradbury et al. (1993) and Yang et al. (2010).

$N_{\text {denit }}=D \mathrm{CO}_{2, \text { soil }} \mathrm{NO}_{3, \text { av }} \frac{W}{W_{\mathrm{s}}}$,

where $D$ is the denitrification rate per $\mathrm{g}$ of $\mathrm{CO}_{2}$ respiration of soil organic matter, the $W$ is soil water in the top five soil layers and $W_{\mathrm{s}}$ is water holding capacity at saturation.

\section{A6 Biological N fixation}

The biological $\mathrm{N}$ fixation in temperate and boreal forests is modified to better represent observations that $\mathrm{N}$ fixing tree species are largely absent from mid- to late-successional forests, but can be present in earlier successional forests (Crews, 1999). Based on biome specific data on $\mathrm{N}$ fixation and evapotranspiration in Cleveland et al. (1999), annual non-symbiotic fixation is a function of annual evapotranspiration and occurs in all ecosystems:

$\mathrm{N}_{\text {fix }, \text { nonsym }}=0.0006 \mathrm{AAET}+0.0117$,

where AAET is annual evapotranspiration of the previous year. Non-symbiotic $\mathrm{N}$ fixation is added to the soil $\mathrm{NH}_{4}^{+}$ pool.

Symbiotic $\mathrm{N}$ fixation is a function of the plant functional type, the proportion of the grid cell occupied by the plant function type, leaf area index, and annual evapotranspiration. Symbiotic N fixed is determined by subtracting the nonsymbiotic relationship described above from the relationship between total $\mathrm{N}$ fixation and evapotranspiration in Cleveland et al. (1999; central relationship in Fig. A1). In grasslands and tropical ecosystems, symbiotic $\mathrm{N}$ fixation is added to the plant labile $\mathrm{N}$ pool. In temperate and boreal forests with leaf area index $<1$, symbiotic $\mathrm{N}$ fixation is also added to the plant labile $\mathrm{N}$ pool, as they are assumed to be early successional and contain some $\mathrm{N}$ fixing plants. No symbiotic $\mathrm{N}$ fixation is added to the plant labile $\mathrm{N}$ pool in temperate and boreal forest with leaf area index $\geq 1$. The overall relationship describing symbiotic $\mathrm{N}$ fixation is

$\mathrm{N}_{\mathrm{fix}, \mathrm{sym}}= \begin{cases}w_{\text {pft }}(0.0018 \mathrm{AAET}-0.0289) & \text { temperate or boreal trees and } \mathrm{LAI}<1 \\ 0 & \text { temperate or boreal trees and } \mathrm{LAI} \geq 1, \\ w_{\text {pft }}(0.0018 \mathrm{AAET}-0.0289) & \text { all other pfts }\end{cases}$

where $w_{\mathrm{pft}}$ is the proportion of the grid cell occupied by the plant functional type. $\mathrm{N}$ fixation is constrained to be $\geq 0 \mathrm{~g} \mathrm{~N} \mathrm{~m}^{-2} \mathrm{yr}^{-1}$. 


\section{A7 Dissolved organic matter dynamics}

Dissolved organic $\mathrm{N}$ losses can be important for maintaining $\mathrm{N}$ limitation (Menge, 2011), especially in ecosystems with low anthropogenic $\mathrm{N}$ inputs (Hedin et al., 1995). A simple representation of the production and leaching of dissolved organic matter is added to the CLM-CN. As presented in Gerber et al. (2010), DOM production is assumed to be a fraction of the turnover of the structural litter pool. In the clm $4 \mathrm{mod}$ model, DOM production is parameterized to be $1.5 \%\left(p_{\text {dom }}\right)$ of the transfer from the lignin-based litter pool (Litter 3) to its receiving soil organic matter pool (SOM 3). So that DOM production does not alter the decomposition rate of the litter pool, the $\mathrm{C}: \mathrm{N}$ ratio of DOM must equal that of the receiving SOM pool. Therefore, the $\mathrm{C}: \mathrm{N}$ of DOM is set to be $10: 1\left(\mathrm{CN}_{\mathrm{DOM}}\right)$. Future research should focus on improving the representation of DOM production so that the $\mathrm{C}: \mathrm{N}$ ratio better matches observations (i.e., more $\mathrm{C}$ produced for the same $\mathrm{N}$ production). However, increasing the $\mathrm{C}: \mathrm{N}$ ratio of the DOM while maintaining the same production of DON will likely have little effect on the $\mathrm{N}$ cycle. All DOM produced is assumed to be unavailable for plant uptake and immobilization. The leaching of DOM is based on the water drainage and the total soil water.

\section{Appendix B}

\section{Model descriptions for intermediary models used in sensitivity analysis}

The series of intermediary models using to the sensitivity analysis are described below:

\section{Model 1 (clm4cn)}

Model 1 is the same as the $\operatorname{clm} 4 \mathrm{cn}$ model described in the main text.

\section{Model 2 (Model $1+$ multi-layer canopy)}

Model 2 adds modifications to the canopy scaling of photosynthesis using a multi-layer approach with updated maximum photosynthetic rates, radiative transfer, leaf photosynthesis, and stomatal conductance described in Bonan et al. (2012, 2011). Model 2 uses Kattge et al. (2009) values for $V_{\text {cmax }}$ (see main text).

\section{Model 3 (Model $2+$ soil buffering)}

Model 3 adds a soil buffering parameter to Model 2. The soil buffering assumes that $19 \%$ of the generic soil inorganic $\mathrm{N}$ pool is available for plant uptake, immobilization into soil organic matter, leaching, and denitrification. The parameter
(19\%) was chosen to represent a distribution of the generic soil inorganic $\mathrm{N}$ pool into $90 \% \mathrm{NH}_{4}^{+}$and $10 \% \mathrm{NO}_{3}^{-}$with the same buffering parameters used in the clm 4 mod model. By assuming $10 \%$ of $\mathrm{N}_{\text {is }} \mathrm{NO}_{3}^{-}$, the model is consistent with the preexisting parameterization of $\mathrm{N}$ available for leaching losses in Models 1 and 2.

\section{Model 4 (Model 3 + less open $\mathbf{N}$ cycle)}

Model 4 creates a less open $\mathrm{N}$ cycle by reducing $\mathrm{N}$ fixation (see Appendix A6). To isolate the impact of a less open $\mathrm{N}$ cycle from the sensitivity to reduced $\mathrm{N}$ inputs, we decreased the proportion of excess soil inorganic $\mathrm{N}$ that was lost as denitrification (from $0.50 \mathrm{day}^{-1}$ to $0.0475 \mathrm{day}^{-1}$ ) to maintain the same preindustrial productivity as Model 3.

\section{Model 5 (Model 4 + reduced denitrification)}

Model 5 reduces the proportion of excess $\mathrm{N}$ that is lost through denitrification $\left(0.013\right.$ day $\left.^{-1}\right)$, setting the preindustrial steady state equal to clm4mod.

\section{Model 6 (Model 5 + Michaelis-Menten approach to plant N uptake)}

Model 6 adds the Michaelis-Menten approach (described in Appendix A1) for simulating plant $\mathrm{N}$ uptake. The parameters used are listed in Table A1. N uptake is only allowed to occur when vegetation is photosynthesizing, thus matching the diurnal cycle of $\mathrm{N}$ uptake found in Models 15. To maintain the same preindustrial steady state as model clm 4 mod, the proportion of excess $\mathrm{N}$ that is denitrified was set to 0.0011 day $^{-1}$.

\section{Model 7 (Model $6+\mathrm{N}$ uptake throughout day)}

Model 7 is equivalent to Model 6 except that $\mathrm{N}$ uptake is allowed to occur throughout the day when leaves are present (i.e. $\mathrm{N}$ uptake also occurs at night). To maintain the same preindustrial steady state as clm4mod, the proportion of excess $\mathrm{N}$ that is denitrified was set to $0.00165 \mathrm{day}^{-1}$.

\section{Model 8 (Model 7 + priority to microbial immobilization)}

In Models 1-7, competition between plant $\mathrm{N}$ uptake and microbial $\mathrm{N}$ uptake was based on the relative $\mathrm{N}$ demand by the two processes. Soil inorganic $\mathrm{N}$ is distributed based on the relative demand. In the Model 8, microbial immobilization is given first priority to the soil inorganic $\mathrm{N}$ required to meet its demand for $\mathrm{N}$. To maintain the same preindustrial steady state as clm4mod, the proportion of excess $\mathrm{N}$ that is denitrified was set to 0.0022 day $^{-1}$. 


\section{Model 9 (Model $8+$ temperature and soil water limitation of denitrification)}

In Models $1-8$, the proportion of excess $\mathrm{N}$ that is denitrified depended only on available N. Model 9 limits denitrification based on soil water and soil temperature (see Appendix A5). To maintain the same preindustrial steady state as clm4mod, the proportion of excess $\mathrm{N}$ that is denitrified was set to 0.0011 day $^{-1}$.

\section{Model 10 (Model $9+$ removed $\mathrm{N}$ gas loss that is proportional to net $\mathbf{N}$ mineralization)}

Model 10 removes the turnover-dependent pathway of $\mathrm{N}$ loss by setting the proportion of net $\mathrm{N}$ mineralization lost as $\mathrm{N}$ gas to zero. To maintain the same preindustrial steady state as clm $4 \mathrm{mod}$, the proportion of excess $\mathrm{N}$ that is denitrified, a concentration-dependent $\mathrm{N}$ loss pathway, was set to 0.029 day $^{-1}$.

\section{Model 11 (Model $10+\mathrm{NH}_{4}^{+}$pool, $\mathrm{NO}_{3}^{-}$pool, and nitrification)}

Model 11 separates the generic soil inorganic $\mathrm{N}$ pool in Models $1-10$ into $\mathrm{NH}_{4}^{+}$and $\mathrm{NO}_{3}^{-}$pools. Model 11 also adds the nitrification process described in Appendix A4. To maintain the same preindustrial steady state as clm4mod, the proportion of $\mathrm{NO}_{3}^{-}$that is denitrified was set to $0.17 \mathrm{day}^{-1}$.

\section{Model 12 (Model 11 + denitrification as a function of heterotrophic respiration)}

Model 12 replaces the temperature limitation of denitrification with a parameter that sets denitrification as a proportion of heterotrophic respiration (see Appendix A5). The proportion is set to $0.097\left(\mathrm{~g} \mathrm{C}^{-1}\right.$ to maintain the same preindustrial steady state as $\mathrm{clm} 4 \mathrm{mod}$.

\section{Model 13 (Model $12+\mathrm{N}_{2} \mathrm{O}$ loss that is proportional to nitrification)}

Model 13 adds a $\mathrm{N}_{2} \mathrm{O}$ loss process where $\mathrm{N}_{2} \mathrm{O}$ production is a proportion (0.02) of nitrification (see Appendix A4). To maintain the same preindustrial steady state as clm4mod, the parameter describing the denitrification rate per $\mathrm{g}$ of soil respiration was set to $0.077(\mathrm{~g} \mathrm{C})^{-1}$.

\section{Model 14 (Model 13 + DON leaching)}

Model 14 adds the production and leaching of dissolved organic $\mathrm{C}$ and $\mathrm{N}$ (see Appendix A6). To maintain the same preindustrial steady state as clm4mod, the parameter describing the denitrification rate per $\mathrm{g}$ of soil respiration was set to $0.05\left(\mathrm{~g} \mathrm{C}^{-1}\right.$.

\section{Model 15 (Model $14+$ plant $\mathrm{N}$ buffering, clm4mod)}

Model 15 includes all the changes described for the clm4mod model (main text and Appendix A). It adds to Model 14 a plant labile $\mathrm{N}$ pool that buffers the availability of $\mathrm{N}$ to meet the $\mathrm{N}$ demand set by the photosynthetic rate, tissue allocation, and tissue $\mathrm{C}: \mathrm{N}$ ratios (see Appendix A1).

Acknowledgements. We would like to thank Cayelan Carey, Timothy Fahey, and Natalie Mahowald for helpful comments on the manuscript. Eric Kluzek, Dan Ricutto, and Peter Thornton provided assistance with the CLM-CN simulations. National Science Foundation (NSF) awards to Peter Hess et al. (NSF-ETBC award \#1021613) the NSF IGERT in Cross-Scale Biogeochemistry and Climate, and the Cornell Biogeochemistry and Environmental Biocomplexity Small Grant Program financially supported the project. NCAR is sponsored by the National Science Foundation. We thank the researchers at the Harvard Forest Chronic Nitrogen Amendment Study and the Michigan Nitrogen Deposition Gradient Study for their hard work producing the $\mathrm{N}$ fertilization data cited in this study.

Edited by: U. Seibt

\section{References}

Aber, J. D., Ollinger, S. V., and Driscoll, C.: Modeling nitrogen saturation in forest ecosystems in response to land use and atmospheric deposition, Ecol. Model., 101, 61-78, 1997.

Aber, J. D., McDowell, W. H., Nadelhoffer, K. J., Magill, A. H., Berntson, G., Kamakea, M., McNulty, S. G., Currie, W., Rustad, L., and Fernandez, I. J.: Nitrogen saturation in temperate forest ecosystems - hypotheses revisited, Bioscience, 48, 921-934, 1998.

Arneth, A., Harrison, S. P., Zaehle, S., Tsigaridis, K., Menon, S., Bartlein, P. J., Feichter, J., Korhola, A., Kulmala, M., O’Donnell, D., Schurgers, G., Sorvari, S., and Vesala, T.: Terrestrial biogeochemical feedbacks in the climate system, Nat. Geosci., 3, 525532, 2010.

Bonan, G. B. and Levis, S.: Quantifying carbon-nitrogen feedbacks in the Community Land Model (CLM4), Geophys. Res. Lett., 37, L07401, doi:10.1029/2010GL042430, 2010.

Bonan, G. B., Lawrence, P. J., Oleson, K., Levis, S., Jung, M., Reichstein, M., Lawrence, D. M., and Swenson, S. C.: Improving canopy processes in the Community Land Model version 4 (CLM4) using global flux fields empirically inferred from FLUXNET data, J. Geophys. Res., 116, G02014, doi:10.1029/2010JG001593, 2011.

Bonan, G. B., Oleson, K. W., Fisher, R. A., Lasslop, G., and Reichstein, M.: Reconciling leaf physiological traits and canopy flux data: Use of the TRY and FLUXNET databases in the Community Land Model version 4 (CLM4), J. Geophys. Res., 117, G02026, doi:10.1029/2011JG001913, 2012. 
Bradbury, N., Whitmore, A., Hart, P., and Jenkinson, D.: Modeling the fate of nitrogen in crop and soil in the years following application of ${ }^{15} \mathrm{~N}$-labeled fertilizer to winter-wheat, J. Agr. Sci., 121, 363-379, 1993.

Butterbach-Bahl, K., Nemitz, E., and Zaehle, S.: Nitrogen as a threat to the European greenhouse balance, in: The European Nitrogen Assessment, edited by: Sutton, M. A., Howard, C. M., Erisman, J. W., Billen, G., Bleeker, A., Grennfelt, P., van Grinsven, H., and Grizzetti, B., Cambridge University Press, Cambridge, 434-462, 2011.

Churkina, G., Caldeira, T. R., von Bloh, W., Trusilova, K., Jung, M., and Dentener, F.: Synergy of rising nitrogen depositions and atmospheric $\mathrm{CO}_{2}$ on land carbon uptake moderately offsets global warming, Global Biogeochem. Cy., 23, GB4027, doi:10.1029/2008GB003291, 2009.

Cleveland, C., Townsend, A., Schimel, D. S., Fisher, H., Howarth, R., Hedin, L. O., Perakis, S., Latty, E., von Fischer, J. C., Elseroad, A., and Wasson, M.: Global patterns of terrestrial biological nitrogen $\left(\mathrm{N}_{2}\right)$ fixation in natural ecosystems, Global Biogeochem. Cy., 13, 623-645, 1999.

Crews, T. E: The presence of nitrogen fixing legumes in terrestrial communities: evolutionary vs. ecological considerations, Biogeochemistry, 46, 233-246, 1999.

de Vries, W., Solberg, S., Dobbertin, M., Sterba, H., Laubhahn, D., van Oijen, M., Evans, C. D., Gundersen, P., Kros, J., Wamelink, G. W. W., Reinds, G. J., and Sutton, M. A.: The impact of nitrogen deposition on carbon sequestration by European forests and heathlands, Forest Ecol. Manag., 258, 1814-1823, 2009.

Felzer, B.: Carbon, nitrogen, and water response to climate and land-use changes in Pennsylvania during the 20th and 21st centuries, Ecol. Model., 240, 49-63, 2012.

Felzer, B. S., Cronin, T. W., Melillo, J. M., Kicklighter, D. W., Schlosser, C. A., and Dangal, S. R. S.: Nitrogen effect on carbonwater coupling in forests, grasslands, and shrublands in the arid western United States. J. Geophys. Res.-Biogeo. 116, G03023, doi:10.1029/2010JG001621, 2011.

Gent, P. R., Danabasoglu, G., Donner, L. J., Holland, M. M., Hunke, E. C., Jayne, S. R., Lawrence, D. M., Neale, R. B., Rasch, P. J., Vertenstein, M., Worley, P. H., Yang, Z.-L., and Zhang, M.: The Community Climate System Model Version 4, J. Climate, 24, 4973-4991, 2011.

Gerber, S., Hedin, L. O., Oppenheimer, M., Pacala, S. W., and Shevliakova, E.: Nitrogen cycling and feedbacks in a global dynamic land model, Global Biogeochem. Cy., 24, GB1001, doi:10.1029/2008GB003336, 2010.

Hedin, L. O., Armesto, J., and Johnson, A.: Patterns of nutrient loss from unpolluted, old-growth temperate forests - evaluation of biogeochemical theory, Ecology, 76, 493-509, 1995.

Hogberg, P., Fan, H., Quist, M., Binkley, D., and Tamm, C.: Tree growth and soil acidification in response to 30 years of experimental nitrogen loading on boreal forest, Glob. Change Biol., 12, 489-499, 2006.

Hyvonen, R., Persson, T., Andersson, S., Olsson, B., Agren, G. I., and Linder, S.: Impact of long-term nitrogen addition on carbon stocks in trees and soils in northern Europe, Biogeochemistry, 89, 121-137, 2008.

Janssens, I. A., Dieleman, W., Luyssaert, S., Subke, J.-A., Reichstein, M., Ceulemans, R., Ciais, P., Dolman, A. J., Grace, J., Matteucci, G., Papale, D., Piao, S. L., Schulze, E. D., Tang, J., and
Law, B. E.: Reduction of forest soil respiration in response to nitrogen deposition, Nat. Geosci., 3, 315-322, 2010.

Kattge, J., Knorr, W., Raddatz, T., and Wirth, C.: Quantifying photosynthetic capacity and its relationship to leaf nitrogen content for global-scale terrestrial biosphere models, Glob. Change Biol., 15, 976-991, 2009.

Lamarque, J.-F., Kiehl, J., Brasseur, G., Butler, T., Cameron-Smith, P., Collins, W., Collins, W. J., Granier, C., Hauglustaine, D., Hess, P. G., Holland, E. A., Horowitz, L. W., Lawrence, M., McKenna, D., Merilees, P., Prather, M., Rasch, P., Rotman, D., Shindell, D. T., and Thornton, P. E.: Assessing future nitrogen deposition and carbon cycle feedback using a multi- model approach: analysis of nitrogen deposition, J. Geophys. Res.Atmos., 110, D19303, doi:10.1029/2005JD005825, 2005.

Lawrence, D. M., Oleson, K., Flanner, M. G., Thornton, P. E., Swenson, S. C., Lawrence, P. J., Zeng, X., Yang, Z.-L., Levis, S., Sakaguchi, K., Bonan, G. B., and Slater, A. G.: Parameterization improvements and functional and structural advances in Version 4 of the Community Land Model, J. Adv. Mod. Earth Sys., 3, M03001, doi:10.1029/2005JD005825, 2011.

Lawrence, P. J., Feddema, J. J., Bonan, G. B., Meehl, G. A., O’Neill, B. C., Oleson, K., Levis, S., Lawrence, D. M., Kluzek, E., Lindsay, K., and Thornton, P. E.: Simulating the biogeochemical and biogeophysical impacts of transient land cover change and wood harvest in the Community Climate System Model (CCSM4) from 1850 to 2100, J. Climate, 25, 3071-3095, 2012.

Liu, L. and Greaver, T. L.: A review of nitrogen enrichment effects on three biogenic GHGs: the $\mathrm{CO}_{2}$ sink may be largely offset by stimulated $\mathrm{N}_{2} \mathrm{O}$ and $\mathrm{CH}_{4}$ emission, Ecol. Lett., 12, 1103-1117, 2009.

Magill, A. H., Aber, J. D., Currie, W., Nadelhoffer, K. J., Martin, M. E., McDowell, W. H., Melillo, J. M., and Steudler, P.: Ecosystem response to 15 years of chronic nitrogen additions at the Harvard Forest LTER, Massachusetts, USA, Forest Ecol. Manag., 196, 728, 2004.

Magnani, F., Mencuccini, M., Borghetti, M., Berbigier, P., Berninger, F., Delzon, S., Grelle, A., Hari, P., Jarvis, P. G., Kolari, P., Kowalski, A. S., Lankreijer, H., Law, B. E., Lindroth, A., Loustau, D., Manca, G., Moncrieff, J. B., Rayment, M., Tedeschi, V., Valentini, R., and Grace, J.: The human footprint in the carbon cycle of temperate and boreal forests, Nature, 447, 848-850, 2007.

McNulty, S. G., Boggs J., Aber, J. D., Rustad L., and Magill, A. $\mathrm{H}$ : Red spruce ecosystem level changes following 14 years of chronic N fertilization, Forest Ecol. Manag., 219, 279-291, 2005.

Menge, D. N. L.: Conditions under which nitrogen can limit steadystate net primary production in a general class of ecosystem models, Ecosystems, 14, 519-532, 2011.

Nadelhoffer, K. J., Emmett, B. A., Gundersen, P., Kjonaas, O. J., Koopmans, C., Schleppi, P., Tietema, A., and Wright, R. F.: Nitrogen deposition makes a minor contribution to carbon sequestration in temperate forests, Nature, 398, 145-148, 1999.

Nadelhoffer, K. J., Colman, B., Currie, W., Magill, A. H., and Aber, J. D.: Decadal-scale fates of ${ }^{15} \mathrm{~N}$ tracers added to oak and pine stands under ambient and elevated $\mathrm{N}$ inputs at the Harvard Forest (USA), Forest Ecol. Manag., 196, 89-107, 2004.

Oren, R., Ellsworth, D., Johnsen, K., Phillips, N., Ewers, B., Maier, C., Schafer, K., McCarthy, H., Hendrey, G., McNulty, S. G., and Katul, G.: Soil fertility limits carbon sequestration by forest 
ecosystems in a $\mathrm{CO}_{2}$-enriched atmosphere, Nature, 411, 469472, 2001.

Parton, W., Holland, E., Del Grosso, S., Hartman, M., Martin, R., Mosier, A., Ojima, D., and Schimel, D. S.: Generalized model for $\mathrm{NO}_{x}$ and $\mathrm{N}_{2} \mathrm{O}$ emissions from soils, J. Geophys. Res.-Atmos., 106, 17403-17419, 2001.

Pinder, R. W., Davidson, E. A., Goodale, C. L., Greaver, T. L., Herrick, J. D., and Liu, L.: Climate change impacts of US reactive nitrogen, P. Natl. Acad. Sci. USA, 15, 7671-7675, 2012.

Pregitzer, K. S., Burton, A. J., Zak, D. R., and Talhelm, A. F.: Simulated chronic nitrogen deposition increases carbon storage in Northern Temperate forests, Glob. Change Biol., 14, 142-153, 2008.

Qian, T., Dai, A., Trenberth, K. E., and Oleson, K. W.: Simulation of global land surface conditions from 1948 to 2004, Part I: forcing data and evaluations, J. Hydrometeorol., 7, 953-975, 2006.

Raich, J. W., Rastetter, E. B., Melillo, J. M, Kicklighter, D. W., Steudler, P. A., Peterson B. J., Grace, A. L., Moore III, B., and Vorosmarty, C. J.: Potential Net Primary Productivity in South America: Application of a Global Model, Ecol. Appl., 1, 399429, 1991.

Randerson, J. T., Hoffman, F. M., Thornton, P. E., Mahowald, N. M, Lindsay, K., Lee, Y.-H., Nevison, C. D., Doney, S. C., Bonan, G. B., Stoeckli, R., Covey, C., Running, S. W., and Fung, I. Y: Systematic assessment of terrestrial biogeochemistry in coupled climate-carbon models, Glob. Change Biol., 15, 2462-2484, 2009

Sokolov, A. P., Kicklighter, D. W., Melillo, J. M., Felzer, B. S., Schlosser, C. A., and Cronin, T. W.: Consequences of considering carbon nitrogen interactions on the feedbacks between climate and the terrestrial carbon cycle, J. Climate, 21, 3776-3796, 2008.

Sutton, M. A., Simpson, D., Levy, P. E., Smith, R. I., Reis, S., van Oijen, M., and de Vries, W.: Uncertainties in the relationship between atmospheric nitrogen deposition and forest carbon sequestration, Glob. Change Biol., 14, 2057-2063, 2008.

Templer, P. H., Mack, M. C., Chapin III, F. S., Christenson, L. M., Compton, J. E., Crook, H. D., Currie, W. S., Curtis, C. J., Dail, D. B., D'Antonio, C. M., Emmett, B. A., Epstein, H., Goodale, C. L., Gundersen, P., Hobbie, S. E., Holland, K., Hooper, D. U., Hungate, B. A., Lamontagne, S., Nadelhoffer, K. J., Osenberg, C., Perakis, S., Schleppi, P., Schimel, J., Schmidt, I. K., Sommerkorn, M., Spoelstra, J., Tietema, A., Wessel, W., and Zak, D. R.: Sinks for nitrogen inputs in terrestrial ecosystems: a metaanalysis of ${ }^{15} \mathrm{~N}$ tracer field studies, Ecology, 93, 1816-1829, 2012.

Thomas, R. Q., Canham, C. D., Weathers, K. C., and Goodale, C. L.: Increased tree carbon storage in response to nitrogen deposition in the US, Nat. Geosci., 3, 13-17, 2010.

Thomas, R. Q., Zeahle, S., Templer, P. H., and Goodale, C. L.: Global patterns of nitrogen limitation: confronting two global biogeochemical models with observations, Glob. Change Biol., doi:10.1111/gcb.12281, in press, 2013.

Thornton, P. E. and Rosenbloom, N. A.: Ecosystem model spin-up: Estimating steady state conditions in a coupled terrestrial carbon and nitrogen cycle model, Ecol. Model., 189, 25-48, 2005.

Thornton, P. E., Law, B. E., Gholz, H., Condit, M. T., Falge, E., Ellsworth, D., Golstein, A., Monson, R. K., Hollinger, D. Y., Falk, M., Chen, J., and Sparks, J. P.: Modeling and measuring the effects of disturbance history and climate on carbon and water budgets in evergreen needleleaf forests, Agr. Forest Meteorol., 113, 185-222, 2002.

Thornton, P. E., Lamarque, J.-F., Rosenbloom, N. A., and Mahowald, N. M.: Influence of carbon- nitrogen cycle coupling on land model response to $\mathrm{CO}_{2}$ fertilization and climate variability, Global Biogeochem. Cy., 21, GB4018, doi:10.1029/2006GB002868, 2007.

Thornton, P. E., Doney, S. C., Lindsay, K., Moore, J. K., Mahowald, N., Randerson, J. T., Fung, I., Lamarque, J.-F., Feddema, J. J., and Lee, Y.-H.: Carbon-nitrogen interactions regulate climate-carbon cycle feedbacks: results from an atmosphereocean general circulation model, Biogeosciences, 6, 2099-2120, doi:10.5194/bg-6-2099-2009, 2009.

Tian, H., Melillo J., Lu, C., Kicklighter D., Liu, M., Ren, W., Xu, X., Chen, G., Zhang, C., Pan, S., Liu, J., and Running, S.: China's terrestrial carbon balance: contributions from multiple global change factors, Global Biogeochem. Cy., 25, GB1007, doi:10.1029/2010GB003838, 2011.

Wallace, Z. P., Lovett, G. M., Hart, J. E., and Machona, B.: Effects of nitrogen saturation on tree growth and death in a mixed-oak forest, Forest Ecol. Manag., 243, 210-218, 2007.

White, M. A., Thornton, P.E., Running, S. W., and Nemani, R. R.: Parameterization and Sensitivity Analysis of the BIOME-BGC Terrestrial Ecosystem Model: Net Primary Production Controls, Earth Interact., 4, 1-85, 2000.

Yang, X., Wittig, V., Jain, A. K., and Post, W. M.: Integration of nitrogen cycle dynamics into the Integrated Science Assessment Model for the study of terrestrial ecosystem responses to global change, Global Biogeochem. Cy., 23, GB4029, doi:10.1029/2009GB003474, 2009.

Zaehle, S. and Dalmonech, D.: Carbon-nitrogen interactions on land at global scales: current understanding in modelling climate biosphere feedbacks, Curr. Opin. Environ. Sust., 3, 311320, 2011.

Zaehle, S. and Friend, A. D.: Carbon and nitrogen cycle dynamics in the O-CN land surface model: 1. Model description, site-scale evaluation, and sensitivity to parameter estimates, Global Biogeochem. Cy., 24, GB1005, doi:10.1029/2009GB003521, 2010.

Zaehle, S., Friend, A. D., Friedlingstein, P., Dentener, F., Peylin, P., and Schulz, M.: Carbon and nitrogen cycle dynamics in the OCN land surface model: 2. Role of the nitrogen cycle in the historical terrestrial carbon balance, Global Biogeochem. Cy., 24, GB1006, doi:10.1029/2009GB003522, 2010a.

Zaehle, S., Friedlingstein, P., and Friend, A. D.: Terrestrial nitrogen feedbacks may accelerate future climate change, Geophys. Res. Lett., 37, L01401, doi:10.1029/2009GL041345, 2010 b.

Zaehle, S., Ciais, P., Friend, A. D., and Prieur, V.: Carbon benefits of anthropogenic reactive nitrogen offset by nitrous oxide emissions, Nat. Geosci., 4, 601-605, 2011.

Zak, D. R., Pregitzer, K. S., Holmes, W. E., Burton, A. J., and Zogg, G. P.: Anthropogenic $\mathrm{N}$ deposition and the fate of ${ }^{15} \mathrm{NO}_{3}^{-}$in a northern hardwood ecosystem, Biogeochemistry, 69, 143-157, 2004. 